\title{
Assessment of Avroman Limestone Formation for Portland Cement Industry, Halabja Area, Kurdistan Region, NE-Iraq
}

\author{
Chro M. Fatah \\ Tola A. Mirza \\ Department of geology \\ College of Science \\ University of Sulaimani, Kurdistan region
}

(Received 23/6/2021 ，Accepted 6/10/2021)

\begin{abstract}
Limestone is the main constituent of the raw materials used in manufacturing cement. In this study, the limestone deposits from the Avroman Formation are evaluated by using chemically and mineralogical techniques for their suitability to be used as a raw material for the cement industry.

Twenty-one samples of limestone are collected from different beds of the Avroman Formation for petrographic study which shows that the limestone samples consist mainly of crystalline calcite. Physical and mechanical tests are performed in addition to the mineralogical and geochemical analysis using x-ray diffraction (XRD), $\mathrm{x}$-ray fluorescence (XRF). Geological review and obtained results show that there is a good potential for industrial-grade limestone. The major clay minerals in the clay samples are chlorite, illite, montmorillonite, were as kaolinite appears as minor clay minerals. The geochemical analysis indicates that the limestone of Avroman formation has a wide range of $\mathrm{CaO}$ (46.13-56.00), $\mathrm{Al}_{2} \mathrm{O}_{3}$ (0.01-0.86), $\mathrm{SiO}_{2}(0.00-1.51), \mathrm{Fe}_{2} \mathrm{O}_{3}$ (0.00-1.25), $\mathrm{MgO}(0.24-0.71), \mathrm{K}_{2} \mathrm{O}, \mathrm{Na}_{2} \mathrm{O}, \mathrm{TiO}_{2}$, and $\mathrm{MnO}$ are traces. The physical properties (water absorption and moisture content) and chemical-mineralogical composition of the formation reflect that the dry process is preferable for the production of Portland cement. Mechanical analyses, especially compressive strength show that the quarrying and crushing will be competitive economically during manufacturing. From the results of the analyses, we conclude that the limestone of the formation and clay material of the study area are of good quality and fulfill the international standards of Portland cement.
\end{abstract}

Keywords: Avroman Limestone, Portland cement, Petrography, Mineralogical analysis, Physical properties.

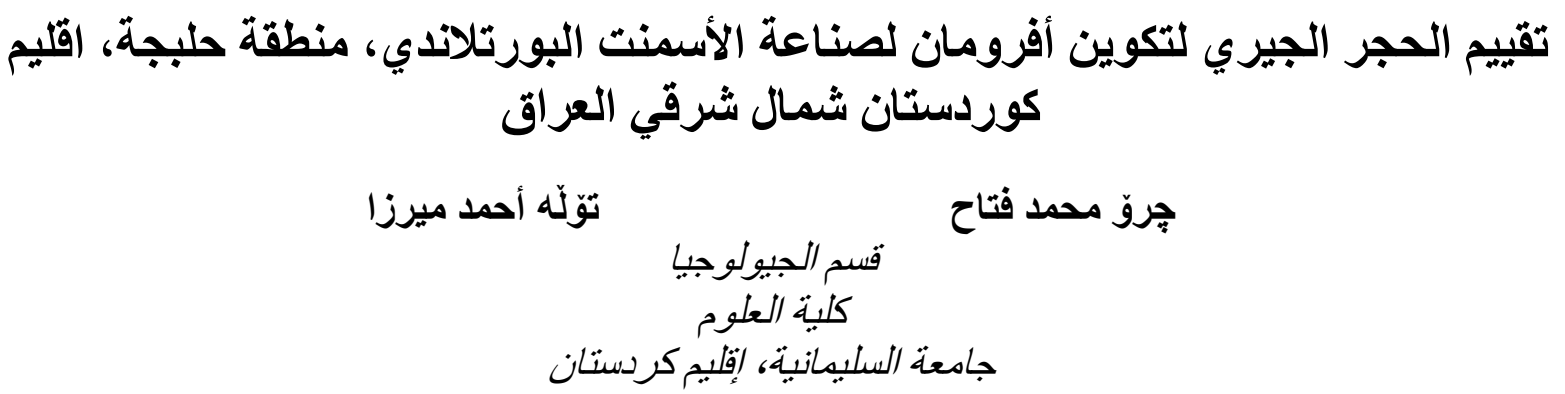




\begin{tabular}{|c|}
\hline 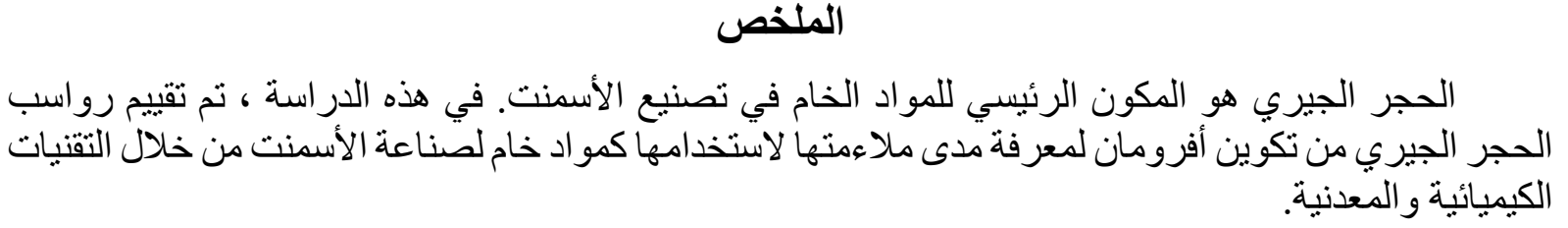 \\
\hline 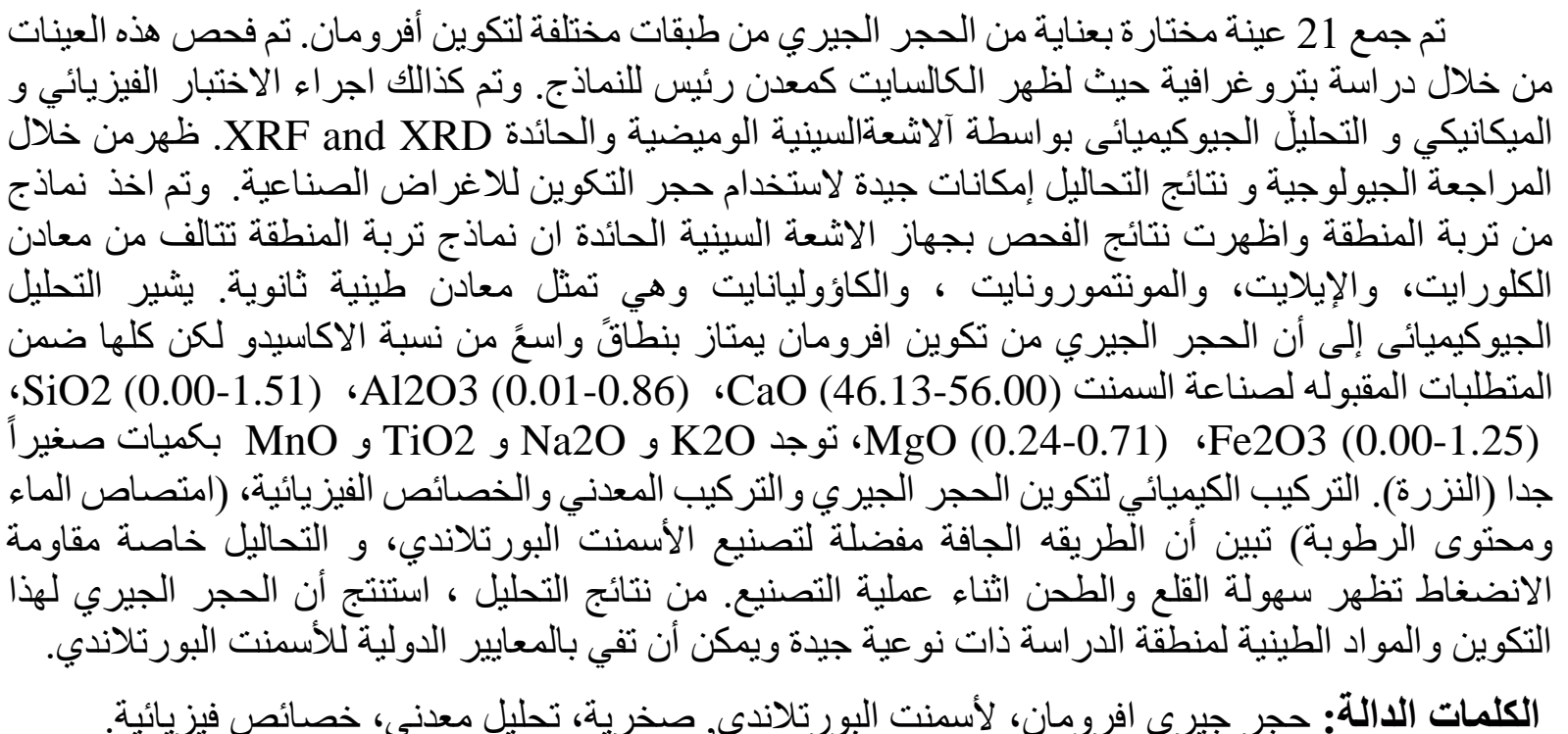 \\
\hline
\end{tabular}

\section{INTRODUCTION}

Limestone is a sedimentary rock composed of calcium carbonate $\left(\mathrm{CaCO}_{3}\right)$. The two most important components are calcite $\left(\mathrm{CaCO}_{3}\right)$ and dolomite $(\mathrm{Ca} \mathrm{Mg} \mathrm{CO} 3)$, but they also contain small amounts of iron-containing carbonates, It can be divided into three main groups: organic, chemical, and detrital or detrital.

In this rapidly developing world, cement plays an important role in the construction industry in every country. As a result, the demand and use of cement are increasing day by day. A new cement factory is being built at a very rapid speed. The industrialization of Portland cement depended on raw materials such as limestone, clay, and gypsum which were considered the key to the success of the cement industry.

Nowadays, in Sulaimani city, Sinjar Formation (Tertiary rocks) is the main raw material for producing cement, but this study tries to find new suitable resources as alternative raw material for Sinjar Formation which is the Avroman Formation (Upper Triassic rocks) to be used for cement industry in the future. In this case, an assessment must be done for raw materials in the study area especially limestone and clay, because successful clinker production demands a clear mixture of limestone, clay, and corrective additives.

\section{GEOLOGY OF STUDY AREA}

The studied area is represented by Suren and Avroman Mountains located within Halabja Governorate and lies between ( $\left.35^{\circ} 17^{\prime} 00^{\prime \prime}-35^{\circ} 20^{\prime} 40^{\prime \prime} \mathrm{N}\right)$ and $\left(46^{\circ} 00^{\prime} 15^{\prime \prime}-\right.$ $46^{\circ} 07^{\prime} 20^{\prime \prime}$ E) (Fig.1). Suren Mountain is bordered by the Sharazoor plain at the southwest, and it is elongated in NW-NE of Khurmal town. This mountain, represented by Avroman Formation, is located in the Qulqula Khwakurk sub zone (Buday and Jassim, 1987) and Zagros Suture Zone. The Avroman limestone Formation outcrops in 
the Zalam valley, Banishar, and Kani Seif areas and comprises about $800 \mathrm{~m}$ of light grey, brownish, sometimes milky white, thick-bedded to massive, hard Limestone (Jassim and Goff, 2006). The range of macrofossils and microfossils is extremely large consisting mainly of megalodons accompanied by encrusted foraminifera, algae, gastropods, and brachiopods. Megedodires indicate the Noric age of the typically lightcolored, massive part dolomitized limestone. The stratigraphy of the formation is obscured by intense deformation inside Iraqi and metamorphism in the Iranian territories; the deformation caused the imbrications and possible thrusting and sliding of the rock (Karim, 2007), and thus it is difficult to identify the lower, middle, and upper parts of the formation. The Avroman Formation is overlain by Qulqula Radiolaria Formation and Merga Red Beds in Iraq and Iran respectively (Fig.1), and the underlying formation is not exposed. The Avroman Limestone which is known as the Bisitoun Shoal Limestone in Iran was deposited on the Bisitoun Micro-continent (Bordenave and Hegre, 2005). It represents a big and narrow continental slab that extends over $400 \mathrm{Km}$ from SW Iran (Lurestan) to the Iraqi Kurdistan region (Ibrahim, 2009). Structurally, the studied area belongs to the imbricated and thrust zone (Buday and Jassim, 1987). The field description shows that the lithology of this formation is pure limestone, generally grey, massive, hard with joints and fractures.

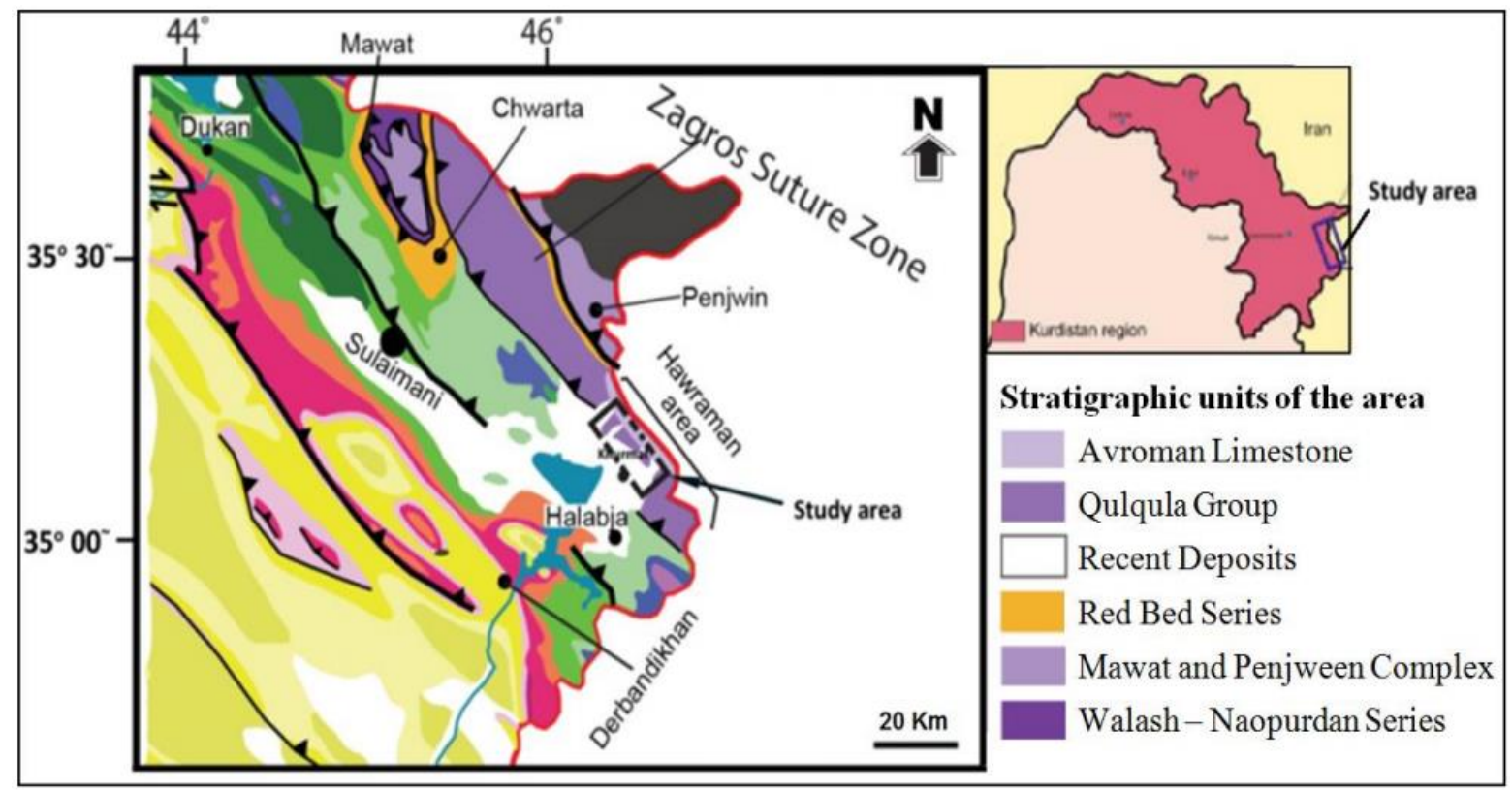

Fig.1: Geological map of North-East Iraq (Lawa, et al., 2013).

\section{MATERIAL AND METHODS}

The fieldwork of this study began with selecting the two suitable sections, Helanpe "H" and Banishar Valley"Bn" sections (Fig.2). The Limestone and soil samples were collected along these two sections. Each collected sample weighs about $5 \mathrm{~kg}$. The thickness of limestone beds cannot be measured in the sections due to thrusting and intensive deformation of the Avroman Formation. The first section is located in the Helanpe village towards the Shanaw valley; in this section 11 samples are collected representing (H1 to H11) (Fig.2). The samples are taken randomly from many large blocks of Avroman limestone Formation which were slumped or slid, and three samples of soil were collected from this area (C5, C6, and C7). The second selected section is in 
Banishar valley where 10 samples are collected toward the direction of the valley from the Avroman limestone Formation as representative samples (Bn1 to Bn10) (Fig.2). As well as one sample of soil is collected from this area (C4), all 8 clay samples are collected from recent valley deposits around the study area. For the petrographical study, 10 thin sections are prepared in the University of Sulaimani Department of Geology and the transmitted microscope model (Magai) is used to distinguish between the calcite and dolomite content, using Alizarin Red stain (Alizarin red solution) and ferric cyanide (pot ferric cyanide solution). Mineralogical analyses are conducted using X-ray diffraction (XRD) for representative limestone and clay samples from the studied area in the laboratories of GEOSURV in Baghdad. For clay samples, oriented and non-oriented samples are prepared for representative clay samples C4 and C5 from each section following the Iraqi Geological Survey standard work procedures, part 21 (Al-Janabi, et al., 1992). The XRD pattern is obtained with a Shimadzu XRD 7000 instrument operating at $45 \mathrm{kV}$ and $40 \mathrm{~mA}$ using $\mathrm{Cu}-\mathrm{K} \alpha$ radiation. The diffraction pattern is between $3^{\circ}-50^{\circ}(2 \Theta)$ for limestone samples while the diffraction pattern for clay samples is between $3^{\circ}-50^{\circ}(2 \theta)$ for non-oriented samples (Bulk sample) and between $3^{\circ}-20^{\circ}(2 \Theta)$ for the oriented sample. The crystalline phase is identified and evaluated by XRD.

The geochemical analysis is carried out by XRF type (Thermo-ARL Advant 'XP + X-ray fluorescence spectrometer) for Limestone samples at Geo Analytical Laboratory, School of Earth and Environmental Science, Washington State University while the clay samples are diagnosed according to the ASTM C114-03 (2003) in Mass Cement Factory in Sulaimaniyah city. The insoluble residue is obtained by the test method (Awad and Mashkour, 1980). The physical properties of limestone were established including (Apparent porosity, apparent specific gravity, Bulk density, water absorption, and Moisture content) in the Department of Geology University of Sulaimani, using (IQS No.31 (1981). The mechanical properties of the limestone samples are done in Engineering Laboratory in Geology Department at the University of Sulaimani to determine the strength of limestone by point load test and converted to unconfined compressive strength. The samples are irregular and core samples and they are classified according to Anon (1972).

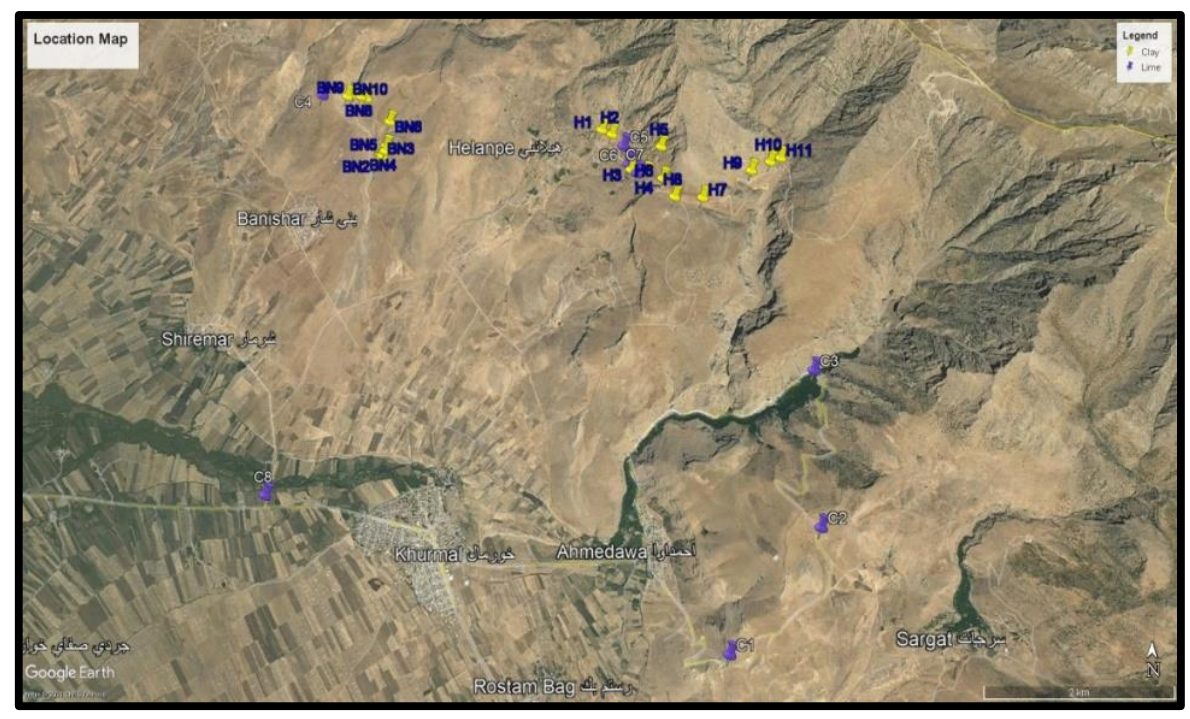

Fig.2. Satellite Image representing the location of the studied area. 


\section{RESULTS AND DISCUSSIONS PETROGRAPHY}

The Petrographic study of limestone samples is carried out. The limestone is fine to coarse-grained clastic texture. In thin sections, different types of minerals present in rocks can be found out based on their optical properties under a polarizing microscope. In this study four samples are analyzed to find the minerals present in limestone, The dominant mineral phase is calcite (Fig.3 A and B). However, quartz is present in small quantities, therefore, it will not create a grinding problem during cement manufacturing.
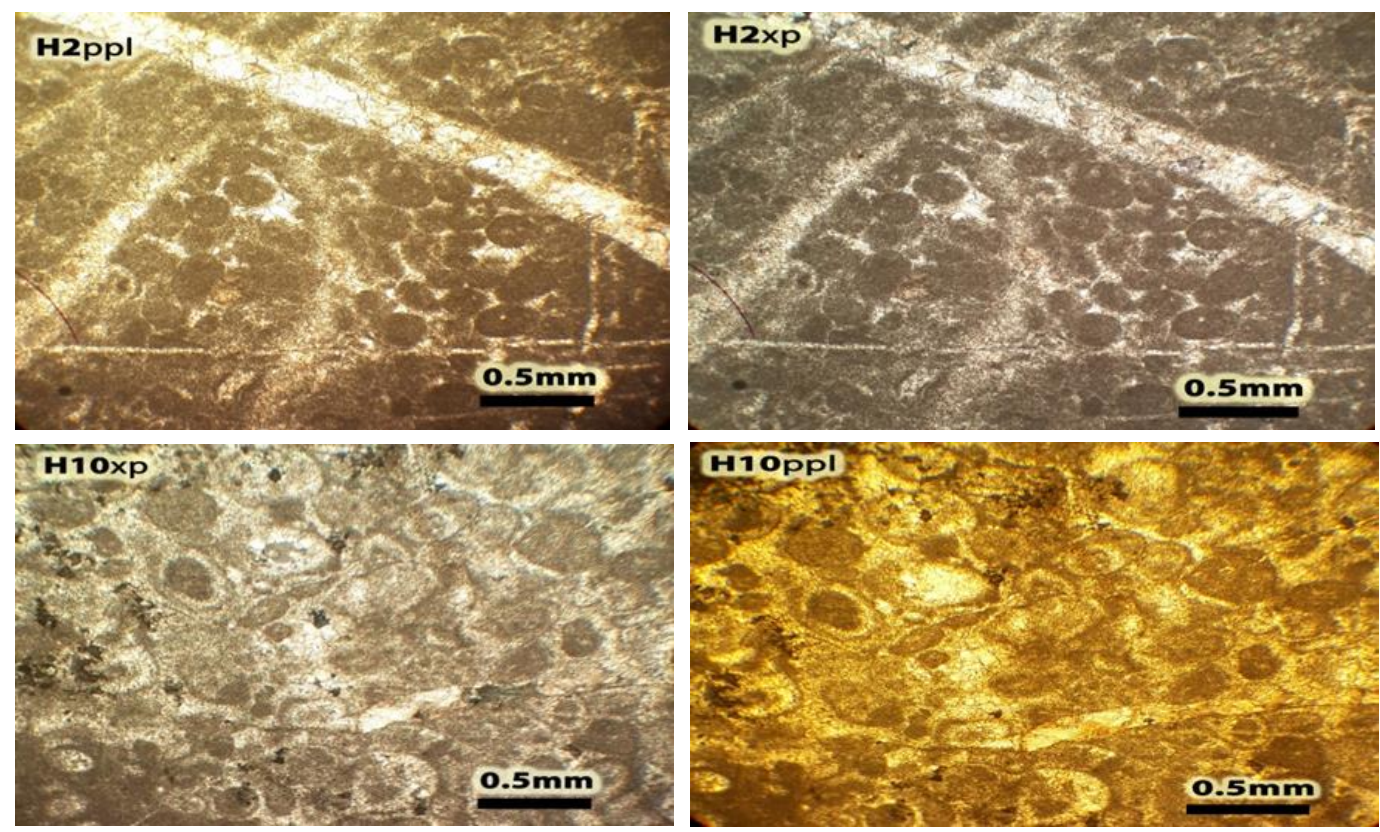

Fig.3A. H2: Intraclastic wackestone with contain vein of calcite.40X, H10: Oolitic packstone to grainstone, which consists of the ghost of ooids.
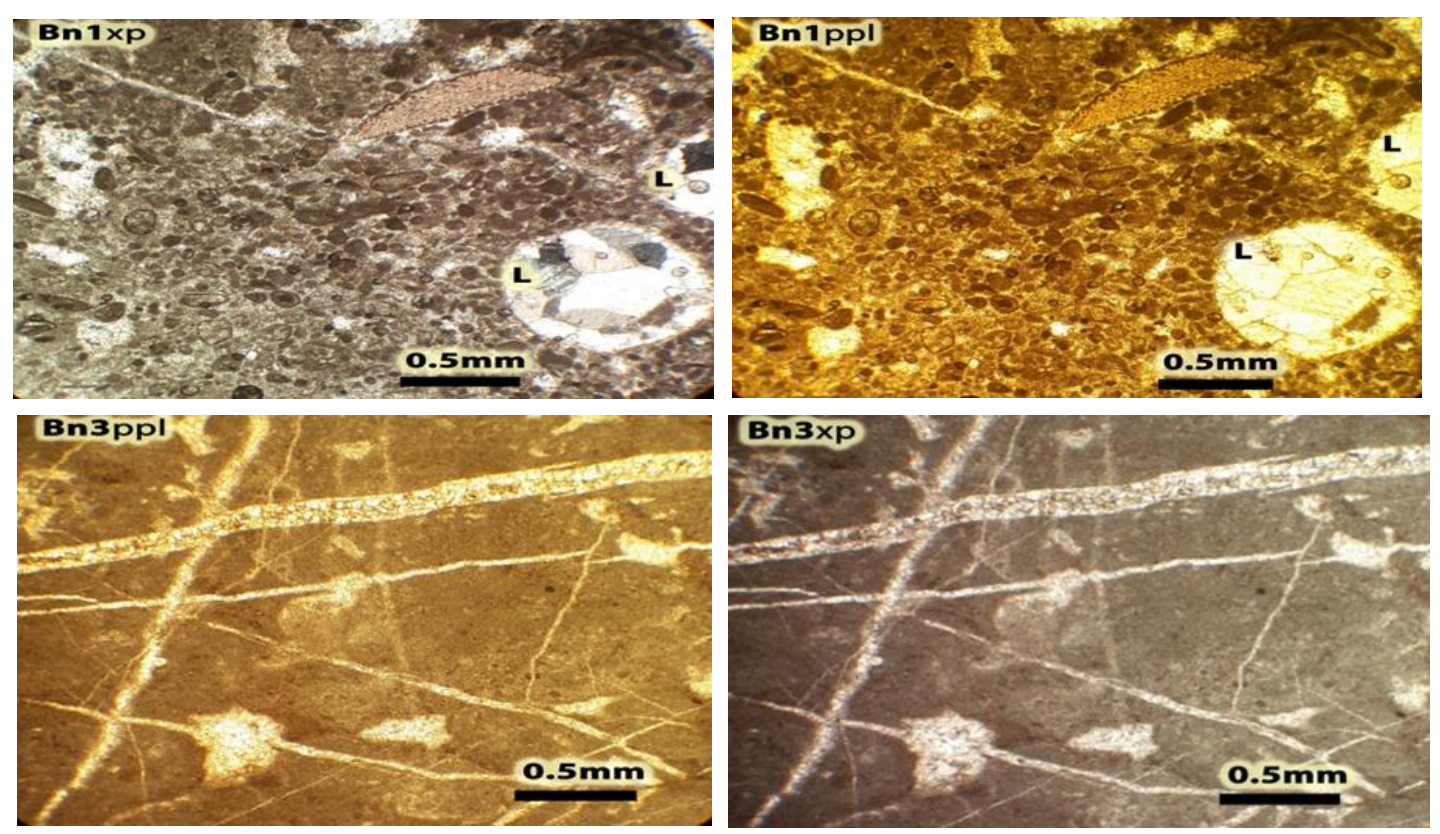

Fig.3B Bn1: Intraclastic, wackestone to packstone with a leaved grain (L) filled by secondary calcite (40X). Bn3: mudstone with high fracture-filled by calcite. 


\section{MINERALOGICAL AND TEXTURAL ANALYSIS}

X-ray Diffraction (XRD) was used for mineral identifications. The identified minerals are present in the following graphs by XRD software X'pert high score. The achieved pattern identified the phases of calcite, dolomite in $\mathrm{H} 10$ and Bn10 samples (Fig.4A and B) which show intense calcite at $\left(23.04^{\circ}, 29.43^{\circ}, 36^{\circ}, 39.43^{\circ}, 43.53^{\circ}\right.$, $47.53^{\circ}$, and $48.55^{\circ}$.), whereas the calcite appears as a dominant mineral phase in the samples $\mathrm{H} 10$ where constitutes more than $99 \%$ and in $\mathrm{Bn} 10$ where constitutes more than $70 \%$ (Table 1). Most $\mathrm{CaO}$ required for cement raw materials comes from calcite (Mirza and Fatah, 2014). The dolomite is obscured except sample Bn10 (Fig.4B) which is present as a less dominant phase after calcite and the percentage is about $29.9 \%$ (Table 1). The intense peak reflection of dolomite is at $\left(31^{\circ}, 41.2^{\circ}\right.$ and $\left.45^{\circ}\right)$ (Fig, $\left.4 \mathrm{~B}\right)$. The XRD pattern of $\mathrm{H} 10$ and $\mathrm{Bn} 10$ is very sharp which indicates the crystalline nature of raw materials. It is very important to note that the limestone must not contain a greater amount of quartz. Otherwise, this will cause the grinding and crushing of limes difficult.

The X-ray diffraction patterns of the representative clays in the studied area (Fig.5A and B; and Fig.6A and B) indicate the presence of non-clay minerals such as (calcite, quartz, and plagioclase). The percentage of non-clay minerals is calculated using the peak area calculation (Table 1) this indicates that quartz is the major non-clay mineral in samples C4and C5(Figs.5A and 6A), while calcite percentage is more in sample C5compared to sample $\mathrm{C} 4$. The main clay minerals in sample $\mathrm{C} 4$ are chlorite, illite, montmorillonite, and kaolinite whereas in sample $\mathrm{C} 5$ there are chlorite illite and montmorillonite (Figs.5B and 6B).

The grain size analysis is established for the clay samples around the study area using wet sieving and hydrometer analysis of these samples. The clay percentage in sample C4 is $36 \%$ while in sample C5 is $46 \%$. The highest value of sand portions in the $\mathrm{C} 4$ and $\mathrm{C} 5$ sample is $36 \%$ and $20 \%$ respectively. The silt portion represents an intermediate size between sand and clay. The maximum percentage of silt in both two studied sections is $34 \%$. The XRD pattern for insoluble residues (I.R.) in carbonate rocks samples (H4, Bn9), (Figs.7A and 7B) show that the most dominant I.R. minerals are clay minerals, quartz, and some of the heavy minerals hematite and pyrite which appear as trace minerals. Moreover, the percentage and weight of insoluble residue for each sample have been determined which lie between $(0.32-3.69) \%,(0.05-0.59) \mathrm{gm}$ respectively for limestone samples; accordingly, the limestone is considered as a pure limestone.

Table 1: Semi-quantitative analysis for studied carbonate and clayey samples.

\begin{tabular}{|c|c|c|c|c|c|c|c|c|c|}
\hline \multirow{3}{*}{$\begin{array}{c}\text { Sample } \\
\text { No. }\end{array}$} & \multicolumn{9}{|c|}{ Semi-quantitative \% of mineral constituents of clayey Samples } \\
\hline & \multicolumn{5}{|c|}{ Clay Minerals \% } & \multicolumn{4}{|c|}{ Non-Clay Minerals \% } \\
\hline & Chlorite & Illite & Montmorillonite & Kaolinite & Total & Calcite & Quartz & Plagioclase \% & Total \\
\hline $\mathrm{C} 4$ & 52.26 & 33.12 & 10.50 & 4.12 & 100.00 & 1.6 & 98.4 & 0.0 & 100 \\
\hline $\mathrm{C} 5$ & 93.30 & 0.95 & 5.70 & 0.00 & 99.95 & 44.5 & 55.3 & 0.0 & 99.8 \\
\hline \multirow{2}{*}{$\begin{array}{c}\text { Carbonate } \\
\text { Rock }\end{array}$} & \multicolumn{9}{|c|}{ Semi-quantitative \% of mineral constituents in Carbonate rock } \\
\hline & \multicolumn{3}{|c|}{ Calcite } & \multicolumn{2}{|c|}{ Dolomite } & Quartz & \multicolumn{3}{|c|}{ Total } \\
\hline H10 & \multicolumn{3}{|c|}{99.80} & \multicolumn{2}{|c|}{0.00} & 0.00 & \multicolumn{3}{|c|}{100.00} \\
\hline Bn10 & \multicolumn{3}{|c|}{70.10} & \multicolumn{2}{|c|}{29.90} & 0.00 & \multicolumn{3}{|c|}{100.00} \\
\hline
\end{tabular}



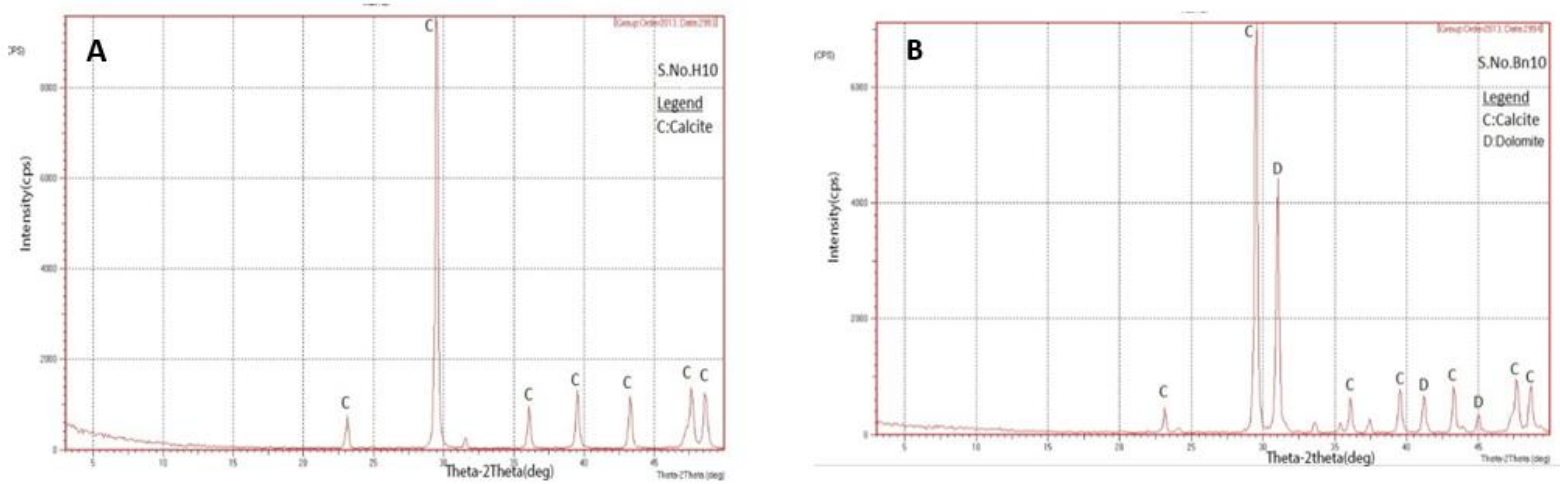

Fig.4: A) X-ray diffraction for limestone Helanpe section (H10). B) X-ray diffraction for limestone Banishar valley section (Bn10).
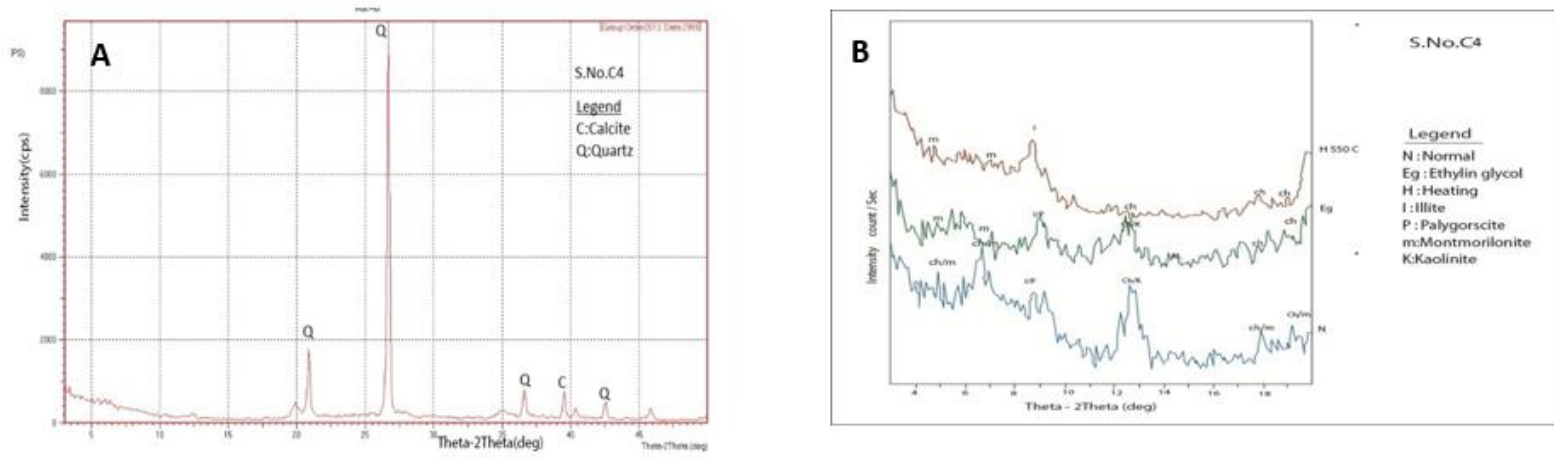

Fig.5: X-ray diffraction patterns of clayey samples from the Banishar valley (sample C4), A) Bulk sample, B), oriented clay fractions at different processing steps.
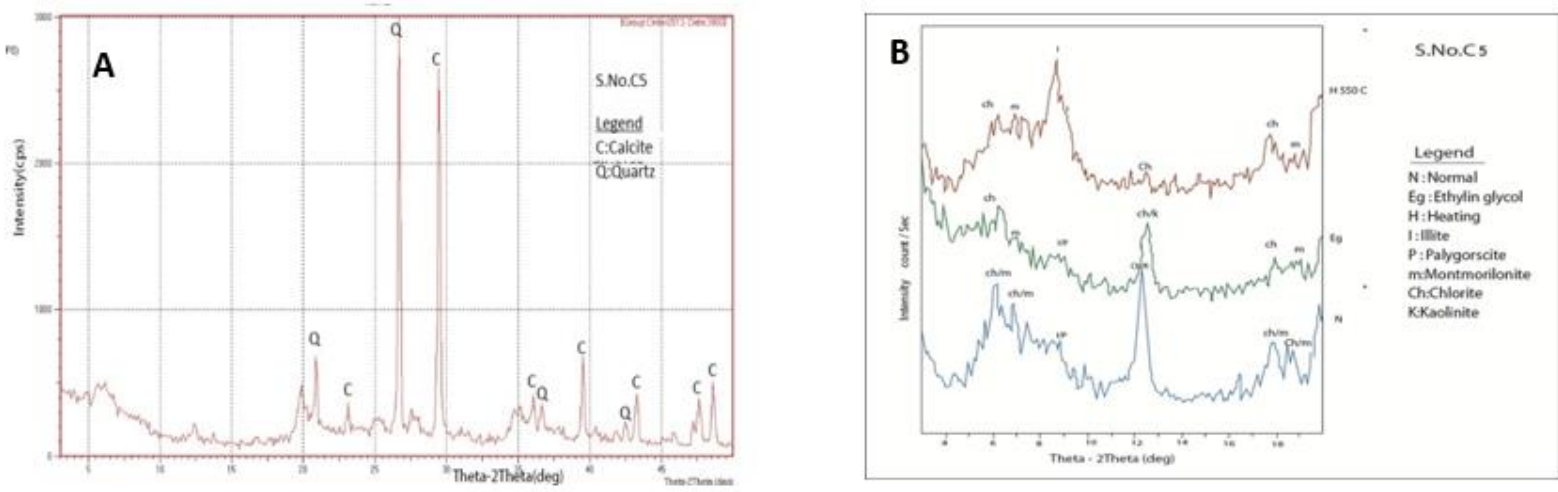

Fig.6: X-ray diffraction patterns of clayey samples from Helanpe (sample C5), A) Bulk sample, B), oriented clay fractions at different processing steps.
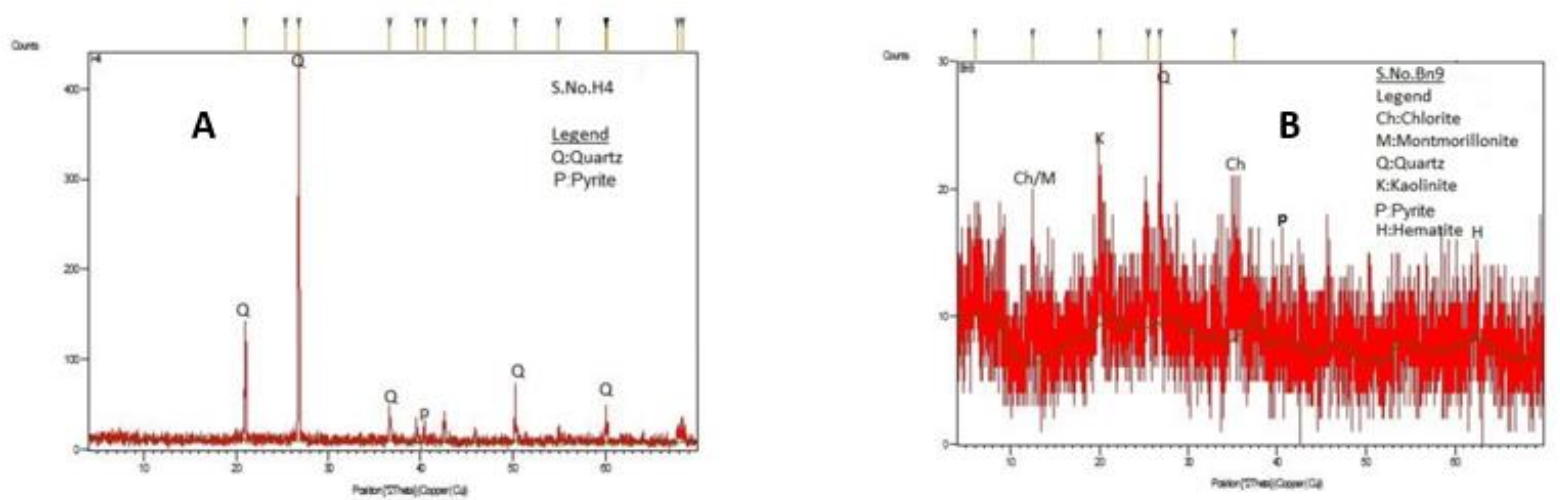

Fig.7: X-ray diffraction for (I.R) limestone A) Helanpe section (H4),B) Banishar valley

(Bn9). 


\section{CHEMICAL ANALYSIS}

The chemical analysis is performed by X-ray fluorescence (XRF) to determine the percentage of major oxides. They are then compared with the results of Duda (1985) (Table 2), who determined the acceptable limits of raw materials for the cement industry and with normal limestone (Clark, 1924 and Amin et al., 2008). The chemistry of the cement in general and Portland cement in particular largely depends upon the geochemistry of its raw materials. Approximately $75 \%$ of the Portland cement raw material consists of lime $(\mathrm{CaO})$ bearing material (Lea, 1976 and Rao et. al. 2011). Portland cement consists mainly of lime $(\mathrm{CaO})$, silica $\left(\mathrm{SiO}_{2}\right)$, alumina $\left(\mathrm{Al}_{2} \mathrm{O}_{3}\right)$, and ferric oxide $\left(\mathrm{Fe}_{2} \mathrm{O}_{3}\right)$ compounds. The combined content of these four oxides (major constituents) is approximately $90 \%$ of the cement weight and the remaining (a minor constituent) of $10 \%$ consists of magnesia $(\mathrm{MgO})$, alkalis $\left(\mathrm{Na}_{2} \mathrm{O}\right.$ and $\left.\mathrm{K}_{2} \mathrm{O}\right)$, chloride $(\mathrm{Cl})$, $\mathrm{SO}_{3}, \mathrm{TiO}_{2}, \mathrm{P}_{2} \mathrm{O}_{5}$ and $\mathrm{MnO}$ (Al-Dabbas, et al., 2013).

\section{QUANTITATIVE CHEMICAL ANALYSIS OF THE LIMESTONE SAMPLES}

The main component of limestone is calcium carbonate $\left(\mathrm{CaCO}_{3}\right)$, which is decomposed into $\mathrm{CaO}$ when heated. According to the data of Table (2). The loss of ignition (LOI) for the studied samples is in agreement with Duda (1985). The high content of LOI in the studied samples is contributed mostly by carbonate minerals $\left(\mathrm{CaCO}_{3}\right)$ for all the samples reaching $>97 \%$ except samples $\mathrm{H} 1$ is $94.75 \%$ and $\mathrm{Bn} 10$ is $82.33 \%$ (Table 2).The average ranges of lime, alumina, silica iron oxide, and magnesia contents falls between $\mathrm{CaO}(46.13-56.00)$ wt. $\%, \mathrm{Al}_{2} \mathrm{O}_{3}(0.01-0.86)$ wt. \%, $\mathrm{SiO}_{2}(0.0-$ $1.51) \mathrm{wt} \%, \mathrm{Fe}_{2} \mathrm{O}_{3}(0.0-1.25)$ wt. $\%$, and $\mathrm{MgO}(0.24-0.71)$ wt. \%, respectively. The high level of magnesia oxide $(\mathrm{MgO})$ in sample $\mathrm{Bn} 10(8.51 \%)$ is related to the few dolomitic bands in the Banishar valley section. The average ranges of alkalis are very low in all studied samples (less than $0.1 \%$ ) (Table 2). With average percentage, $\mathrm{Na}_{2} \mathrm{O}+\mathrm{K}_{2} \mathrm{O}$ reached $(0.021 \%$ and $0.022 \%)$ in $(\mathrm{H}$ and $\mathrm{Bn})$ sections respectively (Tables 3$)$. Sulfur $\left(\mathrm{SO}_{3}\right)$ and phosphorus $\left(\mathrm{P}_{2} \mathrm{O}_{5}\right)$ are regarded as the most undesirable impurities. The presence of $\mathrm{P}_{2} \mathrm{O}_{5}$ slows down the setting time of Portland cement. The $\mathrm{SO}_{3}$ content for all studied samples is less than $0.1 \%$ (Table 2). $\mathrm{The}^{\mathrm{TiO}_{2}}$ and $\mathrm{MnO}$ are present in traces in the studied limestone samples (Table 3). Rao, et al. (2011) believe that the existence of $\mathrm{TiO}_{2}$ and $\mathrm{MnO}$ could be due to the presence of clay materials in the limestone samples. $\mathrm{TiO}_{2}$ generally improves the grindability of the clinkers. $\mathrm{MnO}$ is known as a coloring element and if the concentration is less than $0.5 \%$ the material is very white. The average insoluble residue (IR) in $\mathrm{H}$ and $\mathrm{Bn}$ sections is (1.15 and 1.11) \% respectively (Table 3 ). IR is a non-cement material that will eventually appear in Portland cement. This residue affects the properties of cement, especially the compressive strength. (Kiattikomol et al., 2000 and Hani, 2011).To control the noncementing materials in Portland cement, according to British Standard (B.S. 12, 1996) both two sections have an acceptable limit IR which is less than $1.5 \%$.

For the present samples, the lime saturation factor ranges from (879 to 46829) Table (2) which is very irregular and should be in the uniform range for the production of cement Therefore, for calculating the lime saturation factor of the raw mixture and clinker is set to 90 . While the silica modulus of the studied samples is less than $4 \%$, this 
is due to the very low percentage of $\mathrm{SiO}_{2}, \mathrm{Al}_{2} \mathrm{O}_{3}$, and $\mathrm{Fe}_{2} \mathrm{O}_{3}$. Also, a range of aluminum modulus is less than $4 \%$ in the two studied sections except for a few samples; these samples are (Bn4 and Bn7) in which it reached (10.50 and 6) \%. Some data of the studied samples the SM and AM have shown in (Table 3) do not agree with I.Q.S., No.5 (1984), (Table 4) and therefore, the clay materials are used to make the mixture and modify both SR and AR to agree with the standard specification. The average total carbonate content is between $94.75 \%$ and $99.94 \%$, and the non-carbonate content is between $0.6 \%$ and $5.25 \%$. Therefore, the limestone in the study area is suitable for the industry due to the above factors and its range, except for the sample (Bn10) due to its high magnesium content.

Table 2: Concentration of the main constituents (wt \%) in the samples analyzed by XRF, with LSF (Limestone Saturation Factor), SR (Silica Ratio), and AR (Aluminum Ratio) values.

\begin{tabular}{|c|c|c|c|c|c|c|c|c|c|c|c|c|c|c|c|c|c|c|c|}
\hline Sample no. & $\mathrm{SiO}_{2}$ & $\mathrm{TiO}_{2}$ & $\mathrm{Al}_{2} \mathrm{O}_{3}$ & $\mathrm{Fe}_{2} \mathrm{O}_{3}$ & $\mathrm{MnO}$ & $\mathrm{MgO}$ & $\mathrm{CaO}$ & $\mathrm{SO}_{3}$ & $\mathrm{Na}_{2} \mathrm{O}$ & $\mathrm{K}_{2} \mathrm{O}$ & $\mathrm{P}_{2} \mathrm{O5}$ & Sum & L.0.I & Total & $\mathrm{CaCO}_{3}$ & I.R. & LSF & SR & AR \\
\hline H1 & 1.51 & 0.108 & 0.86 & 1.25 & 0.033 & 0.44 & 53.09 & 0.01 & 0.0 & 0.01 & 0.026 & 57.32 & 42.32 & 99.64 & 94.75 & 2.75 & 879.70 & 0.72 & 0.69 \\
\hline H2 & 0 & 0.002 & 0.01 & 0 & 0.003 & 0.34 & 55.94 & 0.021 & 0.0 & 0.0 & 0.006 & 56.3 & 44 & \begin{tabular}{|l|}
100.3 \\
\end{tabular} & 99.84 & 0.54 & 468291.67 & 0.00 & 0.00 \\
\hline $\mathrm{H} 3$ & 1.05 & 0.125 & 0.8 & 0.85 & 0.008 & 0.7 & 53.69 & 0.048 & 0.0 & 0.02 & 0.018 & 57.25 & 42.4 & 99.65 & 95.82 & 3.69 & 1217.63 & 0.64 & 0.94 \\
\hline $\mathrm{H} 4$ & 0.06 & 0.02 & 0.09 & 0.02 & 0.002 & 0.34 & 55.77 & 0.09 & 0.0 & 0.02 & 0.013 & 56.33 & 43.59 & 99.92 & 99.53 & 0.67 & 19385.81 & 0.55 & 4.50 \\
\hline $\mathrm{H} 5$ & 0.04 & 0.002 & 0.01 & 0.0 & 0.001 & 0.4 & 56.00 & 0.08 & 0.01 & 0.0 & 0.008 & 56.47 & 43.25 & 99.72 & 99.94 & 0.32 & 45403.23 & 4.00 & 0.00 \\
\hline $\mathrm{H} 6$ & n.a & n.a & $\begin{array}{ll}\text { n.a } \\
\end{array}$ & n.a & n.a & n.a & n.a & 0.031 & n.a & n.a & n.a & n.a & n.a & n.a & n.a & 0.60 & n.a & n.a & n.a \\
\hline H7 & 0.51 & 0.033 & 0.32 & 0.1 & 0.003 & 0.57 & 54.7 & 0.06 & 0.0 & 0.09 & 0.01 & 56.32 & 43.33 & 99.65 & 97.62 & 1.41 & 2937.00 & 1.21 & 3.20 \\
\hline H8 & 0.11 & 0.017 & 0.11 & 0.06 & 0.002 & 0.47 & 55.08 & 0.055 & 0.01 & 0.02 & 0.028 & 55.9 & 43.89 & 99.79 & 98.30 & 0.58 & 11572.55 & 0.65 & 1.83 \\
\hline H9 & 0.0 & 0.002 & 0.03 & 0.0 & 0.002 & 0.24 & 56.00 & 0.02 & 0.0 & 0.0 & 0.005 & 56.63 & 42.53 & 99.16 & 99.94 & 0.82 & 156055.56 & 0.00 & 0.00 \\
\hline $\mathrm{H} 10$ & n.a & n.a & n.a & n.a & n.a & n.a & n.a & 0.04 & n.a & n.a & n.a & n.a & n.a & n.a & n.a & 0.61 & n.a & n.a & n.a \\
\hline H11 & 0.01 & 0.002 & 0.02 & 0.0 & 0.001 & 0.57 & 55.78 & 0.06 & 0.01 & 0.0 & 0.008 & 56.4 & 43.82 & 100.22 & 99.55 & 0.63 & 108091.35 & 0.50 & 0.00 \\
\hline $\mathrm{Bn} 1$ & 0.11 & 0.038 & 0.17 & 0.13 & 0.004 & 0.65 & 54.8 & 0.03 & 0.0 & 0.01 & 0.011 & 55.93 & 43.6 & 99.53 & 97.80 & 1.49 & 9268.65 & 0.37 & 1.31 \\
\hline Bn2 & 0.17 & 0.011 & 0.23 & 0.05 & 0.002 & 0.37 & 55.15 & 0.07 & 0.0 & 0.03 & 0.022 & 56.02 & 43.68 & 99.7 & 98.43 & 0.74 & 7065.33 & 0.61 & 4.60 \\
\hline $\mathrm{Bn3}$ & 0.45 & 0.018 & 0.34 & 0.34 & 0.006 & 0.4 & 55.02 & 0.05 & 0.0 & 0.06 & 0.019 & 56.65 & 42.77 & 99.42 & 98.20 & 2.86 & 2928.53 & 0.66 & 1.00 \\
\hline Bn4 & 0.16 & 0.015 & 0.21 & 0.02 & 0.004 & 0.25 & 55.28 & 0.08 & 0.0 & 0.03 & 0.015 & 55.98 & 43.54 & 99.52 & 98.66 & 0.50 & 7779.45 & 0.70 & 10.50 \\
\hline Bn5 & 0.31 & 0.05 & 0.22 & 0.07 & 0.004 & 0.52 & 55.45 & 0.046 & 0.0 & 0.02 & 0.011 & 56.65 & 43.12 & 99.77 & 98.96 & 1.43 & 4742.25 & 1.07 & 3.14 \\
\hline Bn6 & 0.05 & 0.007 & 0.08 & 0.02 & 0.007 & 0.32 & 55.73 & 0.09 & 0.0 & 0.01 & 0.011 & 56.24 & 43.66 & 99.9 & 99.46 & 0.98 & 22477.91 & 0.50 & 4.00 \\
\hline $\mathrm{Bn} 7$ & 0.37 & 0.016 & 0.24 & 0.04 & 0.003 & 0.42 & 55.15 & 0.022 & 0.0 & 0.04 & 0.031 & 56.31 & 43.15 & 99.46 & 98.43 & 1.75 & 4108.52 & 1.32 & 6.00 \\
\hline Bn8 & 0.15 & 0.004 & 0.04 & 0.01 & 0.001 & 0.25 & 56.00 & 0.055 & 0.01 & 0.0 & 0.032 & 56.51 & 42.71 & 99.22 & 99.94 & 0.38 & 11841.41 & 3.00 & 4.00 \\
\hline Bng & 0.1 & 0.003 & 0.04 & 0.01 & 0.003 & 0.35 & 56.00 & 0.021 & 0.0 & 0.0 & 0.008 & 56.51 & 43.11 & 99.62 & 99.94 & 0.48 & 16819.88 & 2.00 & 4.00 \\
\hline Bn10 & 0.13 & 0.003 & 0.06 & 0.07 & 0.021 & 8.51 & 46.13 & 0.1 & 0.0 & 0.01 & 0.018 & 54.95 & 44.52 & 99.47 & 82.33 & 0.48 & 10906.02 & 1.00 & 0.86 \\
\hline
\end{tabular}

Table 3: The comparison between the average composition of the studied limestone from Helanpe and Banishar valley section with that normal limestone (Clark, 1924 and Amin, et al., 2008) and (Duda 1985).

\begin{tabular}{|c|c|c|c|c|c|c|c|c|}
\hline \multirow[b]{2}{*}{ Oxides } & \multicolumn{3}{|c|}{ Helanpe } & \multicolumn{3}{|c|}{ Banishar } & \multirow[b]{2}{*}{ Normal limestone } & \multirow[b]{2}{*}{ Duda 1985} \\
\hline & Min \% & Max \% & AV \% & Min \% & Max \% & AV \% & & \\
\hline $\mathrm{SiO}_{2}$ & 0.00 & 1.51 & 0.366 & 0.05 & 0.45 & 0.20 & 5.19 & $<6.75$ \\
\hline $\mathrm{TiO}_{2}$ & 0.002 & 0.125 & 0.034 & 0.003 & 0.05 & 0.017 & & \\
\hline $\mathrm{Al}_{2} \mathrm{O}_{3}$ & 0.01 & 0.32 & 0.25 & 0.04 & 0.34 & 0.163 & 0.81 & $<2.0$ \\
\hline $\mathrm{Fe}_{2} \mathrm{O}_{3}$ & 0.00 & 1.25 & 0.253 & 0.01 & 0.34 & 0.08 & 0.54 & $<0.66$ \\
\hline $\mathrm{MnO}$ & 0.001 & 0.033 & 0.006 & 0.001 & 0.021 & 0.006 & & \\
\hline MgO & 0.24 & 0.70 & 0.45 & 0.25 & 8.51 & 1.204 & 7.9 & $<2$ \\
\hline $\mathrm{CaO}$ & 53.09 & 56.00 & 55.12 & 46.13 & 56.00 & 54.47 & 42.61 & $>45$ \\
\hline $\mathrm{SO}_{3}$ & 0.01 & 0.09 & 0.05 & 0.021 & 0.10 & 0.056 & & $<1.5$ \\
\hline $\mathrm{Na}_{2} \mathrm{O}$ & 0.00 & 0.01 & 0.003 & 0.00 & 0.01 & 0.001 & & $<0.28$ \\
\hline $\mathrm{K}_{2} \mathrm{O}$ & 0.00 & 0.09 & 0.018 & 0.00 & 0.06 & 0.021 & & $<0.2$ \\
\hline $\mathrm{Na}_{2} \mathrm{O}+\mathrm{K}_{2} \mathrm{O}$ & 0.00 & 0.09 & 0.021 & 0.00 & 0.06 & 0.022 & 0.38 & \\
\hline $\mathrm{P}_{2} \mathrm{O} 5$ & 0.006 & 0.028 & 0.014 & 0.008 & 0.032 & 0.018 & & \\
\hline L.O.I & 42.32 & 44.00 & 43.24 & 42.71 & 44.52 & 43.39 & & $>38$ \\
\hline $\mathrm{CaCO}_{3}$ & 94.75 & 99.94 & 98.37 & 82.33 & 99.94 & 97.22 & & \\
\hline I.R & 0.54 & 3.69 & 1.15 & 0.48 & 2.86 & 1.11 & & \\
\hline LSF & 879.7 & 468291 & 90530 & 4108 & 22477 & 9793 & & \\
\hline SR & 0.00 & 4.00 & 0.92 & 0.37 & 3.00 & 1.12 & & \\
\hline $\mathbf{A R}$ & 0.00 & 4.50 & 1.24 & 0.86 & 10.50 & 3.94 & & \\
\hline
\end{tabular}


Table 4: Comparison of the chemical analysis for the studied samples with I.Q.S., No.5 (1984) for the production of ordinary Portland cement.

\begin{tabular}{|c|c|c|c|c|c|}
\hline & & & & & \\
sample No. & MgO max.5\% & $\left(\mathbf{N a}_{\mathbf{2}} \mathbf{O}_{\mathbf{2}} \mathbf{K}_{\mathbf{2}} \mathbf{O}\right) \mathbf{M a x . 0 . 6 \%}$ & $\mathbf{S O}_{\mathbf{3}} \mathbf{m a x . 2 . 5} \%$ & SR (1.5-4.0) & AR (1.4- 3.5) \\
\hline H1 & 0.44 & 0.01 & 0.01 & 0.72 & 0.69 \\
\hline H2 & 0.34 & 0 & 0.021 & 0 & 0 \\
\hline H4 & 0.7 & 0.02 & 0.048 & 0.64 & 0.94 \\
\hline H5 & 0.34 & 0.02 & 0.09 & 0.55 & 4.5 \\
\hline H6 & 0.4 & 0.01 & 0.08 & 4 & 0 \\
\hline H7 & 0.57 & n.a & 0.031 & n.a & n.a \\
\hline H8 & 0.47 & 0.09 & 0.06 & 1.21 & 3.2 \\
\hline H9 & 0.24 & 0.03 & 0.055 & 0.65 & 1.83 \\
\hline H11 & n.a & 0 & 0.02 & 0 & 0 \\
\hline Bn1 & 0.57 & n.a & 0.04 & n.a & n.a \\
\hline Bn2 & 0.65 & 0.01 & 0.06 & 0.5 & 0 \\
\hline Bn3 & 0.4 & 0.01 & 0.03 & 0.37 & 1.31 \\
\hline Bn4 & 0.25 & 0.03 & 0.07 & 0.61 & 4.6 \\
\hline Bn5 & 0.52 & 0.06 & 0.05 & 0.66 & 1 \\
\hline Bn6 & 0.32 & 0.03 & 0.08 & 0.7 & 10.5 \\
\hline Bn7 & 0.42 & 0.02 & 0.046 & 1.07 & 3.14 \\
\hline Bn8 & 0.25 & 0.01 & 0.09 & 0.5 & 4 \\
\hline Bn9 & 0.35 & 0.04 & 0.022 & 1.32 & 6 \\
\hline Bn10 & 8.51 & 0.01 & 0.055 & 3 & 4 \\
\hline
\end{tabular}

The alkali content in the raw materials that used for cement industry must be less than $<1 \%$ because if it is $>1 \%$ it causes alkali release by cement and circulation in a kiln, these alkalis react with the group of siliceous materials such as opal, chalcedony, tridymite produce an alkali-silica gel. The low alkali content qualifies the materials for use even in low alkali cement predictor which requires the Na-equivalent to be $<0.6 \%$ according to the equation (Na-equivalent $=\mathrm{Na}_{2} \mathrm{O}+0.658 \mathrm{~K}_{2} \mathrm{O}$ ) (Shafer, 1987 and Mehta, 2001). In all the studied samples, the Na-equivalent is within this limit (Table 5). The alkalis are commonly related to clay minerals of the non-carbonate fraction (Thanoon, 1999 and Shafer, 1987). According to Table (2), sodium oxide $\left(\mathrm{Na}_{2} \mathrm{O}\right)$ and potassium oxide $\left(\mathrm{K}_{2} \mathrm{O}\right)$ are traces related to the chemistry of pure limestone.

Table 5: Sodium equivalent values for the studied samples using the Equation derived from Schafer (1987).

\begin{tabular}{|c|c|c|c|}
\hline Sample No. & Na-equivalent & Sample No & Na-equivalent \\
\hline H1 & 0.01 & $\mathrm{Bn} 1$ & 0.01 \\
\hline H2 & 0 & $\mathrm{Bn} 2$ & 0.02 \\
\hline H3 & 0.01 & $\mathrm{Bn} 3$ & 0.04 \\
\hline H4 & 0.01 & $\mathrm{Bn} 4$ & 0.02 \\
\hline H5 & 0.01 & $\mathrm{Bn} 5$ & 0.01 \\
\hline H6 & n.a & $\mathrm{Bn} 6$ & 0.01 \\
\hline H7 & 0.06 & $\mathrm{Bn} 7$ & 0.03 \\
\hline H8 & 0.02 & $\mathrm{Bn} 8$ & 0.01 \\
\hline H9 & 0 & $\mathrm{Bn} 9$ & 0 \\
\hline H10 & $\mathrm{n} . \mathrm{a}$ & $\mathrm{Bn} 10$ & 0.01 \\
\hline H11 & 0.01 & & \\
\hline
\end{tabular}




\section{QUANTITATIVE CHEMICAL ANALYSIS OF THE CLAY SAMPLES}

Clay is used as a raw material for ordinary Portland cement and is considered to be the main source of $\mathrm{SiO}_{2}, \mathrm{Al}_{2} \mathrm{O}_{3}$ and $\mathrm{Fe}_{2} \mathrm{O}_{3}$. The most important clay elements in the study area are shown in (Table 6). From the table, it varies from $\mathrm{SiO}_{2}(70.7$ to $31.1 \mathrm{wt} . \%$ ) and it is the most abundant oxide of clay. $\mathrm{Al}_{2} \mathrm{O}_{3}$ varies from $(9.83-12.27)$ wt $\%$, while $\mathrm{Fe}_{2} \mathrm{O}_{3}$ ranges between $(5.82-10.80) \mathrm{wt} \%$. The $\mathrm{MgO}$ in all the samples is less than 3.45 $\%$, and $\mathrm{Na}_{2} \mathrm{O}, \mathrm{K}_{2} \mathrm{O}, \mathrm{SO}_{3}$ are considered as a trace in the clay samples. The composition of the studied clay is also compared with that normal clay (Table 6) given by Shah, et al., (2007). The $\mathrm{SiO}_{2}$ content of all samples is in close agreement with normal clay. $\mathrm{Fe}_{2} \mathrm{O}_{3}$ is very similar to that of normal clay. Except for $\mathrm{CaO}$, the other constituents are generally low. This is due to the weathering of the surrounding rocks, which are mainly composed of carbonates.

Table 6: Chemical analysis results (wt. \%) for the studied clay samples with a comparison with normal clay given by Shah, et al. (2007).

\begin{tabular}{|l|c|c|c|c|c|c|c|c|c|c|c|}
\hline Sample.No. & $\mathrm{SiO}_{2}$ & $\mathrm{Al}_{2} \mathrm{O}_{3}$ & $\mathrm{Fe}_{2} \mathrm{O}_{3}$ & $\mathbf{C a O}$ & $\mathrm{MgO}$ & $\mathbf{S O}_{3}$ & $\mathrm{Na}_{2} \mathrm{O}$ & $\mathrm{K}_{2} \mathrm{O}$ & L.O.I & ToTal & I.R \\
\hline $\mathbf{C 1}$ & 42.20 & 11.17 & 6.28 & 14.86 & 2.67 & 0.03 & 0.14 & 0.98 & 21.25 & 99.44 & 68.40 \\
\hline $\mathbf{C 2}$ & 59.35 & 10.85 & 6.20 & 4.72 & 2.56 & 0.02 & 0.16 & 1.09 & 13.92 & 98.87 & 81.80 \\
\hline $\mathbf{C 3}$ & 39.94 & 12.27 & 10.80 & 14.09 & 3.45 & 0.03 & 0.17 & 0.93 & 17.54 & 99.22 & 65.60 \\
\hline $\mathbf{C 4}$ & 70.27 & 10.15 & 5.96 & 1.01 & 1.78 & 0.03 & 0.18 & 0.85 & 8.91 & 99.14 & 89.80 \\
\hline $\mathbf{C 5}$ & 42.67 & 13.21 & 8.60 & 10.61 & 2.90 & 0.04 & 0.13 & 0.95 & 20.32 & 99.43 & 81.70 \\
\hline $\mathbf{C 6}$ & 33.80 & 9.83 & 8.26 & 20.66 & 1.72 & 0.06 & 0.13 & 0.79 & 24.94 & 100.19 & 54.80 \\
\hline $\mathbf{C 7}$ & 31.10 & 7.88 & 5.82 & 29.30 & 2.27 & 0.07 & 0.30 & 0.74 & 22.30 & 99.78 & 35.20 \\
\hline $\mathbf{C 8}$ & 53.17 & 11.46 & 7.88 & 5.88 & 2.76 & 0.05 & 0.37 & 1.20 & 16.73 & 99.50 & 85.50 \\
\hline Normal clay & 50.33 & 19.17 & 6.50 & 1.43 & 3.77 & & 0.81 & 2.32 & & & \\
\hline
\end{tabular}

\section{RAW MIXTURE COMPOSITION}

If the required essential ingredient in the ready-cement mixture is not present in the required amount, the modifier is used as the additive. Therefore, finished examples of silica sand and high silicate clay are used as additives (Duda, 1985). The purpose of calculating the composition of the raw mixture is to determine the ratio of raw components to obtain the chemical and mineralogical composition required for clinker. The studied limestone samples have widely differing LSF values ranging from (879 to 46829) (Table 2). Most samples have values above the limits required for high-quality cement; therefore, the clay sample from some areas have been added to limestone to set pointing clinker. In Kurdistan, most cement factories depend on the LSF value which is between $90-100$. For the present samples, the proportion of raw mix composition is calculated using $\mathrm{LSF}=90$, and depending on the final equation, limestone saturation factor (LSF) is used previously, (Alao, 1979). The expected mixing ratio of clay samples (C4 and $\mathrm{C5}$ ) with some limestone of ( $\mathrm{H}$ and $\mathrm{Bn}$ ) section are shown in (Table 7). 
Table 7: Chemical composition of the mixture and cement clinker with produced some properties. When LSF $=90$.

\begin{tabular}{|c|c|c|c|c|c|c|c|c|c|c|c|c|c|}
\hline \multirow{13}{*}{ Raw mix } & Requirments & $\mathrm{H} 1+\mathrm{C} 4$ & $\mathrm{H} 2+\mathrm{C} 4$ & $\mathrm{H} 3+\mathrm{C} 4$ & $\mathrm{H} 1+\mathrm{C} 5$ & $\mathrm{H} 2+\mathrm{C} 5$ & $\mathrm{H} 3+\mathrm{C} 5$ & $\mathrm{Bn} 1+\mathrm{C} 4$ & $\mathrm{Bn} 2+\mathrm{C} 4$ & $\mathrm{Bn} 3+\mathrm{C} 4$ & $\mathrm{Bn} 1+\mathrm{C} 5$ & $\mathrm{Bn} 2+\mathrm{C} 5$ & $\mathrm{Bn} 3+\mathrm{C} 5$ \\
\hline & $X=$ & 0.201 & 0.227 & 0.208 & 0.294 & 0.329 & 0.304 & 0.223 & 0.223 & 0.219 & 0.323 & 0.323 & 0.319 \\
\hline & $\mathrm{Y}=$ & 0.799 & 0.773 & 0.792 & 0.706 & 0.671 & 0.696 & 0.777 & 0.777 & 0.781 & 0.677 & 0.677 & 0.681 \\
\hline & $\mathrm{SiO}_{2}$ & 15.45 & 16.09 & 15.57 & 13.68 & 14.12 & 13.78 & 15.89 & 15.94 & 15.87 & 13.94 & 13.98 & 14.00 \\
\hline & $\mathrm{Al}_{2} \mathrm{O}_{3}$ & 2.74 & 2.33 & 2.76 & 4.51 & 4.38 & 4.60 & 2.42 & 2.46 & 2.51 & 4.41 & 4.45 & 4.47 \\
\hline & $\mathrm{Fe}_{2} \mathrm{O}_{3}$ & 2.21 & 1.36 & 1.92 & 3.43 & 2.85 & 3.22 & 1.44 & 1.38 & 1.58 & 2.88 & 2.83 & 2.99 \\
\hline & $\mathrm{CaO}$ & 42.62 & 43.47 & 42.73 & 40.62 & 41.05 & 40.61 & 42.81 & 43.08 & 43.19 & 40.55 & 40.78 & 40.87 \\
\hline & $\mathrm{MgO}$ & 0.71 & 0.67 & 0.93 & 1.17 & 1.19 & 1.37 & 0.91 & 0.69 & 0.71 & 1.38 & 1.19 & 1.20 \\
\hline & $\mathrm{SO}_{3}$ & 0.01 & 0.02 & 0.04 & 0.02 & 0.03 & 0.05 & 0.03 & 0.06 & 0.05 & 0.03 & 0.06 & 0.05 \\
\hline & $\mathrm{Na}_{2} \mathrm{O}$ & 0.04 & 0.04 & 0.04 & 0.04 & 0.04 & 0.04 & 0.04 & 0.04 & 0.04 & 0.04 & 0.04 & 0.04 \\
\hline & $\mathrm{K} 2 \mathrm{O}$ & 0.18 & 0.19 & 0.19 & 0.29 & 0.31 & 0.30 & 0.20 & 0.21 & 0.23 & 0.32 & 0.33 & 0.35 \\
\hline & L.O.I & 35.62 & 36.05 & 35.45 & 35.89 & 36.25 & 35.72 & 35.88 & 35.94 & 35.37 & 36.12 & 36.17 & 35.65 \\
\hline & ToTal & 99.59 & 100.24 & 99.65 & 99.64 & 100.21 & 99.69 & 99.61 & 99.81 & 99.55 & 99.66 & 99.83 & 99.61 \\
\hline \multirow{10}{*}{ Clinker } & $\mathrm{SiO}_{2}$ & 24.16 & 25.07 & 24.26 & 21.46 & 22.07 & 21.54 & 24.94 & 24.96 & 24.73 & 21.93 & 21.96 & 21.88 \\
\hline & $\mathrm{Al}_{2} \mathrm{O}_{3}$ & 4.29 & 3.63 & 4.30 & 7.08 & 6.84 & 7.18 & 3.79 & 3.85 & 3.91 & 6.93 & 6.99 & 6.99 \\
\hline & $\mathrm{Fe}_{2} \mathrm{O}_{3}$ & 3.45 & 2.13 & 3.00 & 5.37 & 4.45 & 5.04 & 2.26 & 2.16 & 2.46 & 4.54 & 4.44 & 4.68 \\
\hline & $\mathrm{CaO}$ & 66.63 & 67.73 & 66.56 & 63.71 & 64.17 & 63.49 & 67.17 & 67.46 & 67.30 & 63.81 & 64.07 & 63.90 \\
\hline & $\mathrm{MgO}$ & 1.11 & 1.04 & 1.45 & 1.83 & 1.86 & 2.15 & 1.42 & 1.08 & 1.10 & 2.18 & 1.87 & 1.88 \\
\hline & $\mathrm{SO}_{3}$ & 0.02 & 0.04 & 0.07 & 0.03 & 0.04 & 0.07 & 0.05 & 0.10 & 0.07 & 0.05 & 0.09 & 0.07 \\
\hline & $\mathrm{Na}_{2} \mathrm{O}$ & 0.06 & 0.06 & 0.06 & 0.06 & 0.07 & 0.06 & 0.06 & 0.06 & 0.06 & 0.07 & 0.07 & 0.07 \\
\hline & $\mathrm{K} 2 \mathrm{O}$ & 0.28 & 0.30 & 0.30 & 0.45 & 0.49 & 0.48 & 0.31 & 0.34 & 0.37 & 0.50 & 0.52 & 0.54 \\
\hline & L.O.I & 0.00 & 0.00 & 0.00 & 0.00 & 0.00 & 0.00 & 0.00 & 0.00 & 0.00 & 0.00 & 0.00 & 0.00 \\
\hline & ToTal & 100.00 & 100.00 & 100.00 & 100.00 & 100.00 & 100.00 & 100.00 & 100.00 & 100.00 & 100.00 & 100.00 & 100.00 \\
\hline \multirow{4}{*}{ Ratio } & LSF* $^{*}$ & 89.92 & 90.23 & 90.15 & 90.30 & 89.92 & 90.17 & 89.97 & 89.93 & 90.18 & 90.04 & 90.00 & 89.84 \\
\hline & $\mathrm{LSF}^{\star *}$ & 90.00 & 90.00 & 90.00 & 90.00 & 90.00 & 90.00 & 90.00 & 90.00 & 90.00 & 90.00 & 90.00 & 90.00 \\
\hline & SR & 3.12 & 4.35 & 3.32 & 1.72 & 1.95 & 1.76 & 4.12 & 4.15 & 3.88 & 1.91 & 1.92 & 1.88 \\
\hline & AR & 1.24 & 1.71 & 1.44 & 1.32 & 1.54 & 1.43 & 1.68 & 1.78 & 1.59 & 1.53 & 1.57 & 1.49 \\
\hline \multirow{4}{*}{$\begin{array}{l}\text { clinker } \\
\text { phases }\end{array}$} & $\mathrm{C}_{3} \mathrm{~S} \%$ & 53.83 & 57.67 & 53.22 & 40.93 & 41.02 & 39.11 & 55.10 & 55.68 & 56.03 & 39.87 & 40.40 & 40.00 \\
\hline & $\mathrm{C}_{2} \mathrm{~S} \%$ & 28.64 & 28.36 & 29.40 & 30.65 & 32.34 & 32.24 & 29.92 & 29.55 & 28.64 & 32.80 & 32.47 & 32.56 \\
\hline & $\mathrm{C}_{3} \mathrm{~A} \%$ & 5.53 & 6.03 & 6.34 & 9.67 & 10.61 & 10.52 & 6.22 & 6.56 & 6.18 & 10.70 & 11.00 & 10.61 \\
\hline & $\mathrm{C}_{4} \mathrm{AF} \%$ & 10.50 & 6.47 & 9.12 & 16.35 & 13.54 & 15.32 & 6.88 & 6.57 & 7.50 & 13.80 & 13.52 & 14.23 \\
\hline \multirow{4}{*}{$\begin{array}{l}\text { clinker } \\
\text { properties }\end{array}$} & H.M. & 2.09 & 2.20 & 2.11 & 1.88 & 1.92 & 1.88 & 2.17 & 2.18 & 2.16 & 1.91 & 1.92 & 1.90 \\
\hline & M.B.T & 1420.81 & 1486.95 & 1432.49 & 1274.13 & 1306.49 & 1275.76 & 1449.69 & 1454.73 & 1445.87 & 1283.29 & 1287.99 & 1278.80 \\
\hline & B.I & 3.44 & 4.74 & 3.53 & 1.61 & 1.74 & 1.55 & 4.32 & 4.35 & 4.20 & 1.67 & 1.69 & 1.65 \\
\hline & L.Ph. & 22.11 & 17.13 & 21.53 & 35.70 & 33.00 & 35.64 & 18.30 & 18.00 & 18.87 & 33.80 & 33.50 & 34.04 \\
\hline
\end{tabular}

\section{CALCULATION OF CLINKER PARAMETERS (RATIO)}

To ensure the clinker quality, the following composition parameters (moduli) are controlled (SR, AR, and LSF). The silica ratio (SR) $\left(=\mathrm{SiO}_{2}\right.$ wt. $\% / \mathrm{Al}_{2} \mathrm{O}_{3}$ wt. $\%+$ $\mathrm{Fe}_{2} \mathrm{O}_{3}$ wt. \%), the aluminum ratio (AR) $\left(=\mathrm{Al}_{2} \mathrm{O}_{3}\right.$ wt. $\% / \mathrm{Fe}_{2} \mathrm{O}_{3}$ wt. \%) and the lime saturation factor $\mathrm{LSF}\left\{=\mathrm{CaO}\right.$ wt. $\% /\left(2.8 \mathrm{SiO}_{2}\right.$ wt. $\%+1.2 \mathrm{Al}_{2} \mathrm{O}_{3}$ wt. $\%+0.65 \mathrm{Fe}_{2} \mathrm{O}_{3}$ wt. $\%)\}$. The LSF is often referred to as a percentage, so multiply by 100 and this is mostly applied to clinkers.

The limestone saturation factor (LSF): Form the chemical composition of limestone of the studied area (Table 2) it is evident that for manufacturing cement some quantity of clay must be added to compensate the percentage of silica-alumina and iron oxides for the suitable limestone. To ensure the clinker quality, the following composition parameters (moduli) (LSF, SR, and AR) must be controlled.

The LSF controls the ratio of alite to belite in the clinker; a clinker with a higher LSF will have a higher ratio of alite $\mathrm{C} 3 \mathrm{~S}$ to belite $\mathrm{C} 2 \mathrm{~S}$ than a clinker with low LSF. Rao, et al. (2011) believes that free lime is likely to be present in the clinker when the LSF value exceeds $100 \%$. This is because at $\mathrm{LSF}=100$, as a rule, all free lime must combine with bellite to form alite. Moreover, the normal LSF range is $90-98 \%$, but if it is $80 \%$, there is no problem with the cement manufacturing process or cement strength, but it should not go below this range. The LSF in the studied samples ranges between $(89.84$ -90.18), (Table 7) and this shows that all the studied samples are within an acceptable range.

Silica ratio (SR): It is sometimes called silica modulus and has a particularly significant influence on the burning process and some cement properties (Rao, et al., 2011). When 
SR is increased the amount of liquid phase is decreased and vice versa. So SR has a major influence on the formation of the liquid phase. The SR also affects the grindability of the clinker, when there is a more liquid phase which means that SR is low and this causes the lower grindability of the clinker (Tokyay, 1999). Liquid phase $=71 / 0.53+$ SR (Fundal, 1980). When the SR increases the formation of nodules and the chemical reactions may become too slow making it difficult to operate and it is harder to burn. This causes slow setting and hardening of the cement and high strength of cement is obtained. According to Aldieb and Ibrahim (2010), SR ranges between 1.9 - 3.2. Large variation of SR in the clinker can be an indication of poor uniformity in the kiln feed. The SR in the studied limestone samples was less than 4, (Table 2) while when these samples are mixed with clay materials C4 and C5 the SR theoretically changed to (1.88 - 4.35) (Table 6). This indicates that the raw mixed sample studied is within an acceptable range, and this is due to the effect of silica, alumina, and iron content in the clay.

Alumina ratio (AR)or Alumina modulus (AM): The AR determines the potential relative ratio of aluminate to ferrite phase in the clinker, An increase in clinker AR means that there is more aluminate and less ferrite in the clinker (Rao, et al., 2011).

The AR has a significant effect only on clinker formation at low temperatures, affecting the color of clinker and cement. In general, the AR in ordinary Portland cement clinker is usually between 1.0 and 4.0 (Rao, et al., 2011). The AR in the studied raw mixture samples ranges between $(1.24-1.78)$, (Table 7$)$; this indicates that all the studied samples are in agreement with acceptable ranges. While in the studied limestone samples, the AR ranges between (0.0 to 10.50) (Table 2), and this is due to the high purity of limestone samples.

\section{CLINKER PHASE}

The properties of Portland cement are determined mainly by the proportion of its four major clinker phases which are the impure forms of $\mathrm{Ca}_{3} \mathrm{SiO}_{5}$ (alite), $\mathrm{Ca}_{2} \mathrm{SiO}_{4}$ (belite), $\mathrm{Ca}_{3} \mathrm{Al}_{2} \mathrm{O}_{6}$ (tricalcium aluminate), and $\mathrm{C} 4 \mathrm{AF}$ (tetra calcium aluminate ferrite). Other phases such as periclase $(\mathrm{MgO})$, quartz $\left(\mathrm{SiO}_{2}\right)$, free lime $(\mathrm{CaO})$, etc. may also be present in minor amounts, usually less than $1 \%$ by weight (Dutta, 2011). The clinker phases $\mathrm{C}_{3} \mathrm{~S}, \mathrm{C}_{2} \mathrm{~S}, \mathrm{C}_{3} \mathrm{~A}$, and $\mathrm{C}_{4} \mathrm{AF}$ in the studied samples range between $(39.11-57.67)$ $\%,(28.36-32.80),(5.53-11)$, and $(6.47-16.35) \%$ respectively (Table 7$)$. Comparing these results with typical constituents of C3S, C2S, C3A, and C4AF in normal Portland cement by Newman and Choo (2003),(Table 8)it becomes clear that all the studied samples are within the acceptable range.

Table-8: Mineralogical composition expressed as a percentage of Portland cement (based on Newman and Choo, 2003 and Brandt, 2009)

\begin{tabular}{|c|c|c|c|c|c|}
\hline $\begin{array}{c}\text { Cement } \\
\text { Notation }\end{array}$ & $\begin{array}{c}\text { Mineral } \\
\text { Name }\end{array}$ & $\begin{array}{c}\text { Typical level } \\
\text { (Mass \%) }\end{array}$ & $\begin{array}{c}\text { Typical range } \\
\text { (Mass \%) }\end{array}$ & $\begin{array}{c}\text { Typical range } \\
\text { (Studied samples\%) }\end{array}$ & $\begin{array}{c}\text { Chemical } \\
\text { composition }\end{array}$ \\
\hline $\mathrm{C}_{3} \mathrm{~S}$ & Alite & 57 & $38-60$ & $39.11-57.67$ & $3 \mathrm{CaO} . \mathrm{SiO}_{2}$ \\
\hline $\mathrm{C}_{2} \mathrm{~S}$ & Belite & 16 & $15-38$ & $28.36-32.80$ & $2 \mathrm{CaO} . \mathrm{SiO}_{2}$ \\
\hline $\mathrm{C}_{3} \mathrm{~A}$ & Aluminate & 9 & $7-15$ & $5.53-11$ & $3 \mathrm{CaO} . \mathrm{Al}_{2} \mathrm{O}_{3}$ \\
\hline $\mathrm{C}_{4} \mathrm{AF}$ & Ferrite & 10 & $6-18$ & $6.47-16.35$ & $\mathrm{CaO} . \mathrm{Al}_{2} \mathrm{O}_{3} . \mathrm{Fe}_{2} \mathrm{O}_{3}$ \\
\hline
\end{tabular}




\section{CLINKER PROPERTIES}

Some important properties of clinker are calculated. These properties include:

Hydraulic modulus (HM): It is generally limited by the value $1.7-2.3$ (Aldieb and Ibrahim, 2010), and it has the following form: $\mathrm{HM}=\mathrm{CaO} / \mathrm{SiO}_{2}+\mathrm{Al}_{2} \mathrm{O}_{3}+\mathrm{Fe}_{2} \mathrm{O}_{3}$. The higher the $\mathrm{HM}$, the more heat is needed for clinker burning, the strength, especially the initial strength set up, and also the heat hydration increase, while at the same time reducing the resistance of chemical attacks (Rao, et al., 2011). In general, cement with an $\mathrm{HM}$ of less than 1.7 is usually inadequate in strength. Cement with an HM greater than 2.3 has poor stability of volume; Therefore, the HM of the clinker of the studied samples ranges between $(1.88-2.20)$, (Table 7). This means that all the studied samples have an acceptable HM range.

Minimum burning temperature (MBT): The MBT represents the degree to which the liquid phase begins to appear in the furnace, depending on the ratio of $\left(\mathrm{Al}_{2} \mathrm{O}_{3}, \mathrm{Fe}_{2} \mathrm{O}_{3}\right)$ in the material mixture, but $\left(\mathrm{Fe}_{2} \mathrm{O}_{3}\right)$ has a greater effect. The ratio of lime and silica causes augmentation in value which is better not to be less than $\left(1250{ }^{\circ} \mathrm{C}\right)$. This is because this temperature $\left(\mathrm{C}_{3} \mathrm{~S}\right)$ has only begun to appear (Chatterjee, 1979). The MBT is calculated using the following formula: $\mathrm{MBT}^{\circ} \mathrm{C}=1330+4.51 * \mathrm{C}_{3} \mathrm{~S}-3.74 * \mathrm{C}_{3} \mathrm{~A}-12.64 * \mathrm{C}_{4} \mathrm{AF}$. The MBT of clinker in the studied samples ranges between $\left(1274.13^{\circ}-1486.95^{\circ}\right)$, (Table 7) and this means that all the studied samples have an acceptable range of MBT.

Burnability index (BI): It is expressed as the percentage between the phase $\left(\mathrm{C}_{3} \mathrm{~S}\right)$ to total phases $\left(\mathrm{C}_{3} \mathrm{~A}+\mathrm{C}_{4} \mathrm{AF}\right)$ as follows: $\mathrm{BI}=\mathrm{C}_{3} \mathrm{~S} / \mathrm{C}_{3} \mathrm{~A}+\mathrm{C}_{4} \mathrm{AF}$ Sensitivity depends on the chemical composition of the burning mixture of the raw mixture, because any change in the composition leads to a change in sensitivity burning, the BI value of cement ranges from 2.6 to 4.5 (Al-Ali, 2004). This ratio has good sensitivity burning. The BI of clinker of the studied samples ranges from 1.55 to 4.74 indicating that the BI of most samples is below the acceptable range.

Liquid phase at the burning zone (L.Ph.): The liquid phase of the studied samples is calculated as follows:

$$
\text { L.Ph. \% = 3.0 } \mathrm{Al}_{2} \mathrm{O}_{3}+2.25 \mathrm{Fe}_{2} \mathrm{O}_{3}+\mathrm{MgO}+\mathrm{K}_{2} \mathrm{O}+\mathrm{Na}_{2} \mathrm{O}+\mathrm{SO}_{3}\left(1450{ }^{\circ} \mathrm{C}\right)
$$

The acceptable values of $\mathrm{L} . \mathrm{Ph}$ in cement clinker at temperature $1450{ }^{\circ} \mathrm{C}$ are between $23 \%$ to $27 \%$. The L.Ph. of the studied samples ranges between (17.13-35.64), (Table 7). Therefore, most of the studied samples do have not acceptable values. To reduce the liquid phase, it is necessary to add sand to the mixture, because sand is the main source for $\mathrm{SiO}_{2}$.for increasing SR.

\section{PHYSICAL PROPERTIES OF LIMESTONE}

The physical characterization of limestone from the Avroman Formation must be studied because quarry management is an art; most quarries may contain excellent materials that can be easily made into cement (Mirza and Fatah 2018). Therefore the procedure described by IQS No.31 (1981) is used and the results are listed in Table 9. The physical properties of rocks are influenced by the internal shape of the rock, such 
as particle size, pore size, particle shape, pore connectivity, fracture shape, orientation structure, and texture (SchÖn, 2011).

The porosity (P): The porosity of the studied samples ranges between $(1.1-10.29 \%)$, (Table 9). The low porosity of the studied sample produces high compressive strength and this causes difficulties in crushing and grinding of materials (Mirza and Fatah 2018).

The bulk density ( $\rho)$ : The bulk density of the studied samples ranges between $(2.4-$ 2.67), (Table 9), and the high bulk density of the studied samples is related to the low porosity of samples.

Moisture (water) content: ASTM.D2216-10 (2010) is used to determine the moisture content at a standard temperature of $110 \pm 5^{\circ} \mathrm{C}$.

Moisture content $=\{\mathrm{Mw} / \mathrm{Ms}\} * 100$

Where $\operatorname{Mw}\{\mathrm{g}\}$ : mass of water, Ms $\{\mathrm{g}\}$ : mass oven-dry spacemen.

The moisture content of studied samples ranges between $(0.0014-0.0634) \%$, (Table 9). The low moisture content causes low energy consumption during the drying of the raw mixture before burning.

Apparent specific gravity (T): The apparent specific gravity value of the studied samples ranges between $(2.60-2.72) \mathrm{g} / \mathrm{cm} 3$ (Table 9). The low difference between the bulk density and specific gravity values indicates very low pores in the studied samples.

Table 9:Physical properties of the studied limestone.

\begin{tabular}{|c|c|c|c|c|}
\hline & & & & \\
Sample No. & Apparent Porosity\% & Bulk density gm/cm3 & Apparent SPG gm/cm3 & Natural moisture content\% \\
\hline H1 & 3.26 & 2.63 & 2.72 & 0.0278 \\
\hline H2 & 2.34 & 2.54 & 2.6 & 0.109 \\
\hline H3 & 5.06 & 2.57 & 2.71 & 0.0069 \\
\hline H4 & 1.37 & 2.63 & 2.67 & 0.0014 \\
\hline H5 & 2.89 & 2.61 & 2.69 & 0.0058 \\
\hline H6 & 2.29 & 2.6 & 2.67 & 0.0066 \\
\hline H7 & 13.22 & 2.25 & 2.6 & 0.0288 \\
\hline H8 & 3.78 & 2.5 & 2.6 & 0.0634 \\
\hline H9 & 1.1 & 2.67 & 2.7 & 0.0059 \\
\hline H11 & 2.8 & 2.52 & 2.59 & 0.0311 \\
\hline Bn1 & 2.11 & 2.65 & 2.71 & 0.0141 \\
\hline Bn2 & 7.78 & 2.49 & 2.7 & 0.0376 \\
\hline Bn3 & 7.9 & 2.41 & 2.62 & 0.0708 \\
\hline Bn4 & 3.81 & 2.56 & 2.66 & 0.0093 \\
\hline Bn5 & 4.48 & 2.57 & 2.69 & 0.0082 \\
\hline Bn6 & 1.64 & 2.66 & 2.7 & 0.0051 \\
\hline Bn7 & 6.7 & 2.42 & 2.6 & 0.0073 \\
\hline Bn8 & 4.15 & 2.54 & 2.65 & 0.0064 \\
\hline Bn9 & 2.03 & 2.65 & 2.7 & 0.003 \\
\hline Bn10 & 10.29 & 2.4 & 2.67 & 0.0029 \\
\hline
\end{tabular}

\section{MECHANICAL PROPERTIES (UNIAXIAL COMPRESSIVE STRENGTH, UCS) OF LIMESTONE}

Compressive strength measures the failure point and it is defined as many forces including internal cohesion between grains and crystal with an external force that is perpendicular to the sample (Fatuhy, et.al., 1981 in Hussein, 2010). It is used to define the failure point at rock sample during size reduction where the sample is loaded. 
21 specimens are tested using the point load apparatus (ELE-model) in the University of Sulaimaniyah but the uniaxial compression test is also used for comparison. All the tests were done with the samples air-dried in the laboratory. This test is used in samples of different diameters and the results are shown in (Table 10). Anon (1972) classified the rock sample as very strong if the values of UCS range between $100-200 \mathrm{MN} / \mathrm{m} 2$ and strong if the UCS range between $50-100 \mathrm{MN} / \mathrm{m}^{2}$. Accordingly, the studied limestone samples are classified as moderately strong to very strong. The compressive strength of limestone for the cement industry must be less than $(950-1000) \mathrm{Kg} / \mathrm{cm} 3$, but according to world standard, the value of the compressive strength of limestone ranges between (458.81-1414.0) $\mathrm{Kg} / \mathrm{cm}^{3}$ (Chatterjee, 2004). The results of UCS values for the studied samples in $\mathrm{H}$ and Bn-sections range between (405-1502) $\mathrm{Kg} / \mathrm{cm} 2$ and (200-1464) $\mathrm{Kg} / \mathrm{cm} 2$ respectively. Comparing these results with the world standard for compressive strength of limestone by Chatterjee (2004) indicates all studied samples are in agreement with a standard range of the international world range of limestone. The increasing and decreasing of compressive strength are related to the porosity that is present in the samples; the strength increases, with porosity decreases. Moreover, joints and fractures affect the compressive strength of this rock. From the above results, it can be concluded that the processes of crushing and grinding need a suitable force (energy) during the extraction of a sample in the quarry.

Table 10: The results of uniaxial compressive strength (UCS) of limestone samples for each studied section; Helanpe $(\mathrm{H})$ and Banishar valley $(\mathrm{Bn})$ section.

\begin{tabular}{|c|c|c|c|c|c|c|c|}
\hline Sample No. & $P(K N)$ & De $(\mathrm{mm})$ & $\begin{array}{l}\text { Is =p/De^2 } \\
\left(\mathrm{MN} / \mathrm{m}^{\wedge} 2\right)\end{array}$ & $\begin{array}{c}\text { Is50 }=F^{*} I s\left(\mathrm{Mn} / \mathrm{m}^{\wedge} 2\right) \\
\mathrm{F}=(\mathrm{De} / 50)^{\wedge} 0.45\end{array}$ & \begin{tabular}{|c|} 
UNS (Mpa) \\
UNS $=22.5^{*}$ Is50
\end{tabular} & UNS (Kg/cm^2) & $\begin{array}{l}\text { Classification } \\
\text { (after Anon,1972) }\end{array}$ \\
\hline H1 & 7.20 & 39.00 & 4.73 & 4.23 & 95 & 971 & strong \\
\hline $\mathrm{H} 2$ & 7.00 & 39.00 & 4.60 & 4.12 & 93 & 944 & strong \\
\hline H3 & 4.80 & 39.00 & 3.16 & 2.82 & 63 & 647 & strong \\
\hline H4 & 3.80 & 39.00 & 2.50 & 2.23 & 50 & 513 & strong \\
\hline H5 & 7.50 & 36.00 & 5.79 & 4.99 & 112 & 1145 & Very strong \\
\hline H6 & 7.00 & 39.00 & 4.60 & 4.12 & 93 & 944 & strong \\
\hline H7 & 8.00 & 22.00 & 16.53 & 11.42 & 257 & 2621 & strong \\
\hline H8 & 3.00 & 39.00 & 1.97 & 1.76 & 40 & 405 & Moderately strong \\
\hline H9 & 7.50 & 39.00 & 4.93 & 4.41 & 99 & 1012 & strong \\
\hline H10 & 9.00 & 34.00 & 7.79 & 6.55 & 147 & 1502 & Very strong \\
\hline H11 & 7.00 & 37.00 & 5.11 & 4.47 & 100 & 1024 & Very strong \\
\hline Bn1 & 10.20 & 39.00 & 6.71 & 6.00 & 135 & 1376 & Very strong \\
\hline Bn2 & 8.00 & 36.00 & 6.17 & 5.32 & 120 & 1222 & strong \\
\hline $\mathrm{Bn3}$ & 6.20 & 39.00 & 4.08 & 3.65 & 82 & 836 & strong \\
\hline Bn4 & 7.50 & 39.00 & 4.93 & 4.41 & 99 & 1012 & strong \\
\hline Bn5 & 10.20 & 32.00 & 9.96 & 8.15 & 183 & 1870 & Very strong \\
\hline Bn6 & 5.00 & 32.00 & 4.88 & 3.99 & 90 & 916 & strong \\
\hline Bn7 & 1.60 & 39.00 & 1.05 & 0.94 & 21 & 216 & strong \\
\hline Bn8 & 10.00 & 37.00 & 7.30 & 6.38 & 144 & 1464 & Very strong \\
\hline Bn9 & 6.00 & 39.00 & 3.94 & 3.53 & 79 & 809 & strong \\
\hline Bn10 & 7.20 & 39.00 & 4.73 & 4.23 & 95 & 971 & strong \\
\hline
\end{tabular}

\section{CONCLUSIONS}

- From the petrography study, four microfacies have been identified which are: Intraclastic wackestone, oolitic packstone to grainstone, wackestone to packstone, and mudstone. The microfossils are relatively rare except Echinoid, Plecypod, Foram, and some unknown bioclast.

- The limestone Avroman Formation which is identified through petrographical and mineralogical analysis shows that the predominant carbonate mineral is calcite. 
- The chemical analyses of 21 limestone samples and 8 clay samples show that limestone contains qualified raw materials suitable for the cement industry.

- The LSF is very high this indicates that limestone has high purity for present samples the LSF ranges from (879 to 46829), this ratio needs to be uniform with the range needed for cement making; therefore, clinker compositions and estimating the proportions of raw mix clay and limestone are calculated depending on fixed LSF ( 90).

- $\quad$ Chemical modules of clinker LSF, SR, AR, Clinker phase $\left(\mathrm{C}_{3} \mathrm{~S}, \mathrm{C}_{2} \mathrm{~S}, \mathrm{C}_{3} \mathrm{~A}\right.$, and $\mathrm{C} 4 \mathrm{AF}$ ) and cement properties such as hydraulic modules and minimum burnability temperature, most are within the standard specification for manufacturing Portland cement.

- The results of the physical properties test (moisture content) show that the dry process is preferable for the production of Portland cement.

- The mechanical property of the Avroman Limestone Formation indicates that the limestone is moderately strong to very strong according to the classification of Anon (1972) hence it needs a suitable force during the extraction and crushing.

\section{ACKNOWLEDGMENTS}

The author would like to thank the Mass Cement Company for their support. Also, we would like to thank Professor Dr. Kamal H. Karim, Department of Geology, and the University of Sulaimani for his help in the identification of microfacies. We would like to thank also Dr. Mazn Muhammad of in Physic Department, the University of Basra for his support in the mineralogical analysis of insoluble residue by XRD.

\section{REFERENCES}

Adams, A.E., Mukerizie, W.S. and Guilford, C., 1987. Atlas of sedimentary rocks under the microscope, published in the United States of America by Halsted Press, a division of John Wiley and Sons, Inc. 104 P.

Alao, A.W., 1979. Chemical and mineralogical assessment of Okeluse-Arimogija limestone and shale deposits as raw materials for the production of Portland cement, Unpublished. M.Sc. thesis, Univ. of Hull, 87 P.

Al-Ali, S.H.A., 2004. Assessment of cement produced at Kufa cement plants and the raw materials used in its manufacture. Unpublished, M.Sc. thesis, University of Basrah, 100 P (in Arabic).

Aldieb, M.A. and Ibrahim, H.G., Member IAENG, 2010. Variation of Feed Chemical Composition and its Effect on Clinker Formation-Simulation Process, proceeding of the world congress on engineering and computer Science, San Francisco, USA.

Al-Dabbas, M., Awadh, S.M. and Abid Zaid, A., 2013. Mineralogy, geochemistry, and reserve estimation of the Euphrates limestone for Portland cement industry at Al-Najaf area, south Iraq. Arabian Journal of Geosciences, Vol.6, No.2, pp.491 $-503$. 
Al-Janabi, Y., Al-Saadi, N., Zainal, Y., Al-Bassam, K. and Al-Delaimy, M., 1992. GEOSURV Work Procedures, Part 21: Chemical Laboratories. GEOSURV, int. rep. no. 1991, 1992.

Amin, N., Ali, K. and Shah, M., 2008. Chemical study of limestone and clay for cement manufacturing in Darukhula, Nizampur District, Nowshera, northwest Frontier Province (N.W.F.P), Pakistan. Chinese. Journal of geochemistry. Vol.27, No.3, pp. $242-248$.

Anon, 1972. The preparation of maps and plans in terms of engineering geology. Quarterly Journal of Engineering Geology, Vol.5, pp. 293 - 382.

ASTM.C114-03, 2003. "Standard Test Methods for Chemical Analysis of Hydraulic Cement" Annual Book of ASTM Standards, Vol.04.01, Cement; lime; Gypsum, pp. $109-138$.

ASTM. D2216-10, 2010. Standard test methods for laboratory determination of water (moisture) content of soil and rock by mass. ASTM International, West Conshohocken, PA, 2010. doi: 10.1520/D2216-10. pp. 1 - 7.

Awad, S. A., and Mashkour, M., 1980. Principles of Geological Techniques, Ministry of Higher Education and Scientific Research, Baghdad, 275 P (in Arabic).

Bordenave, M.L. and Hegre, J. A., 2005. The influence tectonic on the entrapment of oil in the Dezful Embayment, Zagros Fold belt, Iran, Journal of petroleum geology, Vol.28, No.4, pp. 339 - 368.

BS 12, 1996. Specification for Portland cement, 15thed., British Standards Institution, London.

Brandt, A. M., 2009. Cement-Based Composites. 2nd ed., Taylor \& Francis, London, UK. 536 P.

Buday, T. and Jassim, S.Z., 1987. The Regional Geology of Iraq: Vol.2, Tectonism, Magmatism, and Metamorphism. I.I. Kassab and M.J. Abbas (Eds.), Geosurv, Baghdad, 445pp.

Chatterjee, A.K., 1979. Phase composition, microstructure quality and burning of Portland cement-a review of phenomenological interrelations- Part 2, World cement technology, Vol.10, No.5, pp. $165-172$.

Chatterjee, A.K., 2004. Raw materials selection. In: Bhatty, J.I., (edit), innovation in Portland cement manufacturing Portland cement association Illinois, USA., pp. $37-63$.

Clark, F.W., 1924. Bull. U.S. Geol. Surv., No.770, 841 P.

Duda, W.H., 1985. "Cement - Data Book" International process engineering in the cement industry, $3^{\text {rd }}$. Bauverlag, GmbH, Wiesbaden and Berlin, Macdonald and Evans, London, $636 \mathrm{P}$.

Dutta, D., 2011. Utilization of Blast Furnace Slag as a Raw Material for Manufacturing of Portland Cement Clinker, MS.C, thesis, National Institute of Technology Rourkela, Ceramic Engineering, 67 P. 
Fundal, E., 1980. Microscopy of cement raw mix and clinker. Internal report of F.L.Smidth laboratories on cement chemistry, Copenhagen, Denmark, 15 P.

Hani, F.F.B., 2011. Chemical Analysis of Ordinary Portland Cement of Jordan. Ass. Univ. Bull. Environ. Res. Vol.14, No.1, pp. 1 - 9.

Hussein, S.A., 2010. Geochemical, Petrographic, and petrophysical studies to evaluate the suitability of limestone for cement industry in the outcrops of Fatha Formation, Sukkaria area, west of Baiji. Iraqi Journal of Science. The University of Tikrit. Tikrit-Iraq. Vol.51, No.1, pp. 107-122. (In Arabic).

Ibrahim, A.O. 2009. Tectonic style and evolution of the NW segment of the Zagros Fold - Thrust belt, Sulaimaniyah Governorate, Kurdistan region, NE Iraq. Unpublished Ph.D. thesis, University of Sulaimani, College of Science, 187 P.

I.Q.S No.31, 1981. Iraqi standard specification for measurement of Bulk density, specific gravity, Moisture content, apparent porosity, Water absorption of limestone rock for product of Portland cement.

I.Q.S, No.5, 1984. Iraqi Standard Specification, Portland cement (In Arabic).

Jassim, S.Z., and Goff, J.C., 2006. Geology of Iraq, published by Dolin, Prague and Moravian Museum, Brno, $341 \mathrm{P}$.

Karim, K.H., 2007. Lithology and stratigraphy of Avroman Formation (Triassic) NE Iraq, Iraqi Journal of earth science, Vol.7, No.1, pp. $1-12$.

Kiattikomol, K., Jaturapitakkul, C., and Tangpagasit, J., 2000. Effect of insoluble residue on properties of Portland cement. Cement and Concrete Research, Vol.30, pp. 1209 - 1214.

Lawa, F.A., Koyi, H., and Ibrahim, A., 2013. Tectono-Stratigraphic Evolution of the NW Segment of the Zagros Fold - Thrust Belt, Kurdistan, NE Iraq. Journal of Petroleum Geology, Vol.36, No.1, pp. 75 - 96.

Lea F. M., 1 976. "Chemistry of Cement and Concrete (3 Edition) [M]": Edward Arnold (Publishers) Ltd., U.K.

Mehta, P. K. and Monteiro, P., 2001. Concrete: Microstructure, Properties, and Materials, 2nd ed., The McGraw-Hill Companies Inc., 548 P.

Mirza T.A. and Fatah C. M., 2018. Evaluating the suitability of Avroman limestone, Halabja governorate for cement industry; Iraqi Bulletin of Geology and Mining Vol.14, No.1, pp. 103 -120.

Newman, J. and Choo, B.S., 2003. Advanced Concrete Technology; Constituent Materials. $1^{\text {st }}$, Butterworth Heinemann, Elsevier, UK, 288 P.

Rao, D.S.,Vijayakumar, T.V., Prabhakar, S.and Bhaskar Raju, G., 2011. Geochemical Assessment of a Siliceous Limestone Sample for cement making. Chines Journal of Geochemistry. Vol.30, Issue 1, pp. 33 - 39.

Schafer, H.U., 1987. Assessment of raw materials for the cement industry. Reprint from the journal ,world cement ${ }^{\text {ee }}$ Cement and Concrete Association, London, Vol.7, pp. $273-283$. 
SchÖn, J.H., 2011. Physical properties of Rocks, A workbook, Elsevier, Vol.8, 481 P.

Shah, M.T., Fayez, A., and Ali, L., 2007. Chemical study of the Raw Material in Gandghar Range, District Haripur, NWFP, for Portland Cement Manufacturing. Jour. Chem. Soc. Pak., Vol.29, No.2, pp. $103-110$.

Tokyay, M., 1999. Effect of the chemical composition of clinker on grinding energy requirement. Cement and carbonate research, Vol.29, Issue 4, pp. $531-536$. 